\title{
Mathematical Analysis of Solar Photovoltaic Array Configurations with Partial Shaded Modules
}

\author{
*V. Bala Raju, Dr. Ch. Chengaiah \\ Dept. of EEE, SV University College of Engg., Tirupati, India
}

Received February 24, 2020; Accepted April 22, 2020; Published April 28, 2020

\begin{abstract}
Solar-based photovoltaic (SPV) cells produce power from sunlight through the photovoltaic effect. The yield voltage of a single PV cell is small, so the voltage is extended by interfacing PV cells in series arrangement known as PV module or panel. Solar PV array comprises of series and parallel connections of modules in the grid structure with a few columns and rows. The various kinds of SPV array configurations or topologies are shaped by changing the number of electrical connections between module to module in an array. This paper presents the mathematical examination of $6 \times 6$ size regular SPV array configurations, including Total-Cross-Tied, Parallel, Honey-Comb, Series-Parallel, Series, Bridge-Linked types beneath un-shading case, and different proposed shading cases (primarily short narrow, short wide, long narrow, and long wide shadings). The electrical proportionate circuit of the SPV array setups was analyzed by Kirchhoff's laws at distinctive nodes and loops in a sun powered PV array. The location of global maximum power point (GMPP) was determined hypothetically and distinguished in Matlab/simulation software at various shading conditions.
\end{abstract}

Keywords: Photovoltaic cell; Module; Array; Configurations; Shaded modules; Row currents; PV array power.

\section{Introduction}

The expanded electrical energy demand around the world, ecological issues, and the global warming effect due to the use of fossil fuels have brought about the developing selection of sustainable power sources for power generation. Sustainable power source is an elective wellspring of electrical energy for providing the necessary energy demand. Among all renewable energy sources, the photovoltaic (PV) system has a more preferred position than other sources, because of the most recent improvement in PV innovation, value drop of PV modules or panels, rugged and simple in design requiring very little maintenance, subsidies provided by the government, no pollution etc. [1]. Solar-based PV (SPV) power is gotten by the immediate transformation strategy for sunlight into power. The exhibition of the SPV system relies upon solar-based irradiance, shading effect, maturing impact, temperature, and degradation impacts, and so on. The most influencing factors are temperature and solar-based irradiance [2-3]. The sun-oriented PV system has a unique extreme power point (MPP) under uniform irradiance case, and numerous peaks happen under non-uniform irradiance cases, for example, local peaks, global peaks. This global peak point is considered on the yield $\mathrm{P}-\mathrm{V}$ characteristics [4]. 
Solar-oriented PV cells can straightforwardly convert the sun powered capacity into the electrical power and be associated through various interconnections of cells to achieve more power. The sun-based PV panel or module is shaped by arranging PV cells in series, while the PV array is framed by the series and parallel association of PV panels. The quantity of interconnections between modules in a array are changed to make the diverse SPV exhibit association topologies, for example, Series, Bridge-Link, Parallel, Total-Cross-Tied (TCT), Series-Parallel, and Honey-Comb types [5]. Among all topologies, TCT has least mismatch, low shading losses, and high producing yield power [6]. Many researchers have introduced literature reviews on solar PV array configurations under incomplete shading conditions [7-10].

This paper presents the mathematical examination of a $6 \times 6$ SPV array arrangement under four shading cases including short narrow (SN), long wide (LW), short wide (SW) and long narrow (LN) shadings, and one un-shading case (U). The mathematical examination of a $6 \times 6$ size regular designs was gotten from Kirchhoff's laws, i.e., Kirchhoff's current law (KCL) was applied at hubs, and Kirchhoff's voltage law (KVL) was applied at closed loops.

This paper initially discusses the modeling of a single diode photovoltaic cell, module, and array in Section 2. Different conventional SPV arrangements are introduced in Section 3. In Sections 4 and 5, the numerical investigation of conventional type configurations under the non-shading case and four shading cases and furthermore reproduction results for a $6 \times 6$ array designs are introduced. In Section 6, conclusions are given.

\section{Modeling of Solar Photovoltaic System}

\subsection{Modeling of Photovoltaic Cell, Module, and Array}

Sun oriented photovoltaic cells directly convert photon energy from sun based irradiance into DC electricity through the photovoltaic effect. Each cell generates a small amount of the current, and these cells are connected in series to form a single module or panel and produce higher currents. The combination of series and parallel connected PV panels forms a SPV array.

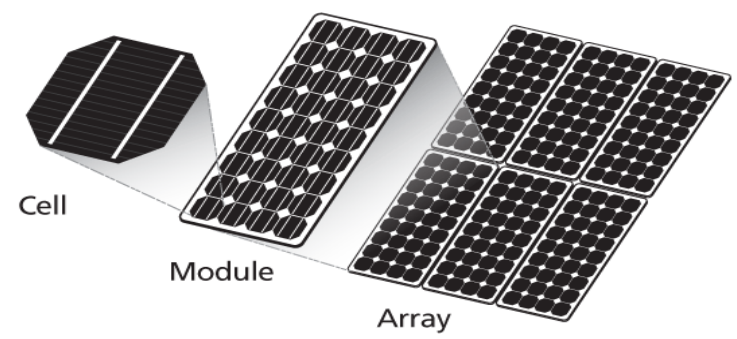

Figure 1. Formation of the solar PV cell to an array.

Figure 1 shows the formation of the SPV array with several cells and modules. The simplified models of single diode PV cell and PV array are shown in Figure 2 and 
Figure 3, respectively. The solar PV array is made by series-connected $\left(\mathrm{N}_{\mathrm{S}}\right)$ and parallel connected $\left(\mathrm{N}_{\mathrm{P}}\right)$ PV panels.

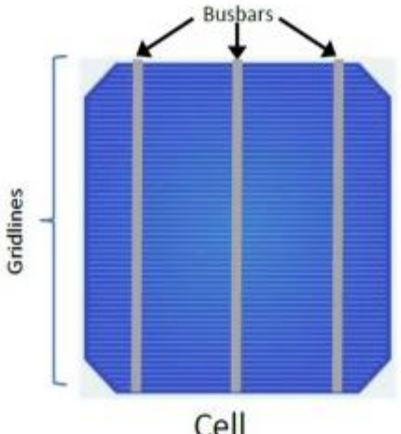

(a)

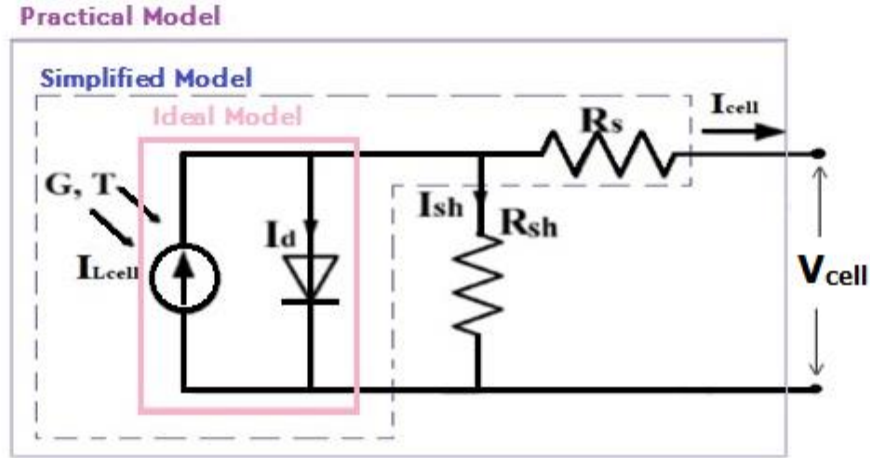

(b)

Figure 2. (a) Single diode solar PV cell (b) Equivalent circuit of a PV cell

The mathematical representation of a PV cell is given in Equation 1 [11].

$$
I_{\text {cell }}=I_{\text {Lcell }}-I_{0}\left[\exp \left\{\frac{q\left(V_{\text {cell }}+I_{\text {cell }} R_{S}\right)}{K a T_{c}}\right\}-1\right]-\frac{\left(V_{\text {cell }}+I_{\text {cell }} R_{S}\right)}{R_{S H}}
$$

Figure 3. Circuit of solar photovoltaic array

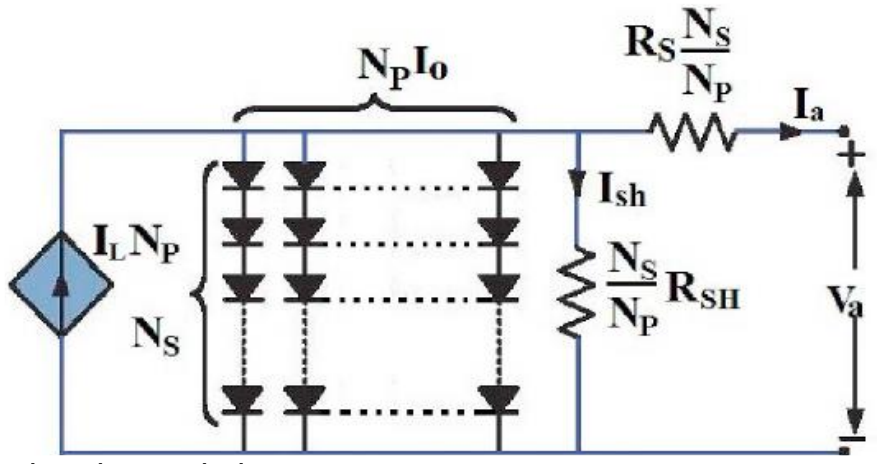

The mathematical representation of the PV module given in Equation 2,

$$
I_{m}=I_{L}-I_{0}\left[\exp \left\{\frac{q\left(V_{m}+I_{m} R_{S}\right)}{n_{s} K a T_{c}}\right\}-1\right]-\frac{\left(V_{m}+I_{m} R_{S}\right)}{R_{S H}}
$$

where $I_{L}$ is the current generated by the module light, represented as

$$
I_{L}=\frac{G}{G_{0}}\left[I_{L S T C}+K_{i S C}\left(T_{c}-T_{S T C}\right)\right]
$$

where, $K_{i s c}$ is the module short circuit co-efficient, $I_{L S T C}$ the current generated by the module light at STC (Standard Test Conditions). $G$ is the incident irradiance, and $G_{0}$ is the standard irradiation. $\mathrm{I}_{\mathrm{m}}$ and $\mathrm{V}_{\mathrm{m}}$ are output current and voltage of $\mathrm{PV}$ module, $\mathrm{I}_{\text {cell }}$ and 
$\mathrm{V}_{\text {cell }}$ are output current and voltage of a single diode PV cell, ILcell is photo generated current of a solar PV cell and $\mathrm{I}_{0}$ is reverse saturation current.

The simplified mathematical equation of PV array [10-11] is given by

$$
I_{a}=N_{P} \cdot I_{L}-N_{P} \cdot I_{0}\left[\exp \left\{\frac{q\left(V_{a}+\frac{N_{S}}{N_{P}} I_{a} R_{S}\right)}{N_{S} K a T_{c}}\right\}-1\right]-\frac{\left(V_{a}+\frac{N_{S}}{N_{P}} I_{a} R_{S}\right)}{\frac{N_{S}}{N_{P}} \cdot R_{S H}}
$$

where, $N_{P}$ and $N_{S}$ are the total number of parallel and series connected panels in the SPV array, $R_{S H}$ and $R_{S}$ are parallel and series resistances of the module, $V_{a}$ and $I_{a}$ are the voltage and current of the SPV array. $I_{L}$ denotes the photo-electric current, $I_{o}$ is reverse saturation current, $q$ : charge, $a$ : diode ideality factor, $k$ : Boltzmann constant and $T$ is the temperature of the solar cell at STC.

The above set of equations is used to model the PV array to simulate I-V and P-V characteristics with the help of parameters in the datasheet of a solar PV module.

\section{Solar PV Array Configurations}

\subsection{Conventional Solar PV Array Configurations}

There are six basic PV array configurations available which are known as a conventional type of configurations or topologies. From this conventional type, hybrid PV array topologies are developed by combining any two conventional type configurations. The primary conventional configurations of PV array are [12]:

a. Simple Series (SS) connection

b. Series-Parallel (S-P) connection

c. Bridge-Linked (B-L) connection

d. Simple Parallel (SP) connection

e. Total-Cross-Tied (T-C-T) connection

f. Honey-Comb (H-C) connection configuration.

Figure 4 shows the conventional array configurations of a $6 \times 6$ size solar PV array.

Simple-Series (SS): In this connection, one module is connected to another module like a series connection, as shown in Figure 4(a). In a series connection, the total voltage is the sum of each module voltages, so the output array voltage is high in a SS topology.

Simple-Parallel $(\boldsymbol{P})$ : In this connection, all SPV modules are parallel connected, as shown in Figure 4(b). In a parallel connection, the total current is the sum of each module currents, so the output array current is high in a parallel topology.

Series-Parallel (SP): In this type, the number of series-connected modules called strings is connected to form a series-parallel (SP) topology, as displayed in Figure 4(c).

Bridge-Link (BL): This BL topology is adapted from a wheat-stone bridge, and this scheme is derived from the bridge rectifier connections, as shown in Figure 4(e). 
Honey-Comb $(\boldsymbol{H C})$ : In this connection, solar PV panels are connected in hexagon shape by the honeycomb architecture, as shown in Figure 4(f).

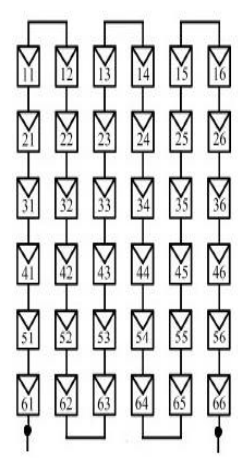

(a) $\mathrm{S}$

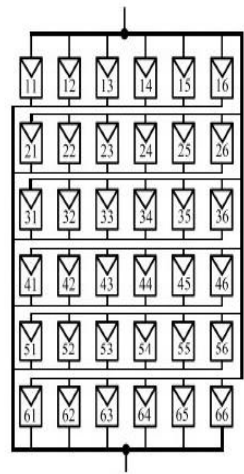

(b) $\mathrm{P}$

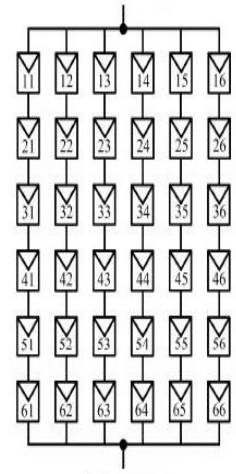

(c) SP

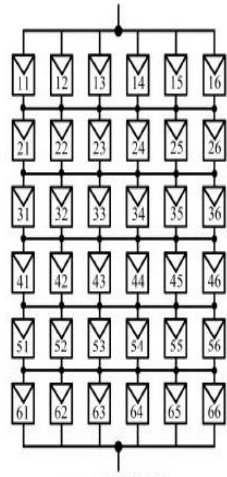

(d) TCT

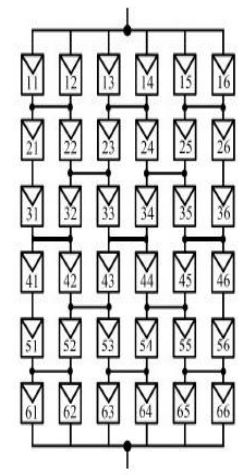

(e) BL

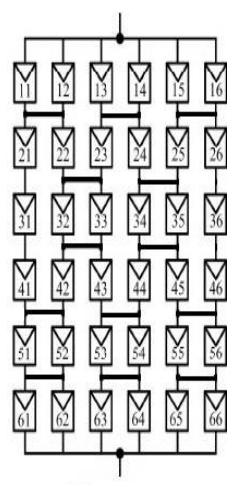

(f) $\mathrm{HC}$

Figure 4. $6 \times 6$ Solar PV array conventional configurations

Total-Cross-Tied (TCT): This TCT connection is formed by establishing the electrical contacts or ties among the rows and columns of the S-P connection topology, as shown in Figure 4(d).

In this TCT connection, SPV modules are connected in matrix form. The labeled number $\mathbf{m n}$ in matrix form indicates; first index $\mathbf{m}$ represents the row number and second index $\mathbf{n}$ represents the column number. For example, in a $6 \times 6$ connected SPV array $1^{\text {st }}$ row consists of PV modules labeling from 11 (1st row and 1st column) to 16 (1st row and 6th column), and the $1^{\text {st }}$ column consists of modules from 11 (1st row and 1st column) to 61 (6th row and 1st column), as shown in Figure 4.

\section{Mathematical Analysis of SPV Array Configurations}

In this section, mathematical examination is performed for a $6 \times 6$ size $\mathrm{PV}$ array conventional configuration, appeared in Figures 5 to 10. The mathematical is performed with the assistance of Kirchhoff's laws, i.e., Kirchhoff's current law is applied at nodes and Kirchhoff's voltage law is applied at closed loops.

\subsection{Different Interconnection Array Configurations}

\section{(i) Simple Series Configuration}

The simplest topology or configuration of the PV system is Simple Series connection type, as shown in Figure 5. Where $I_{P V}$ and $V_{P V}$ are the current and voltage of the PV array. 


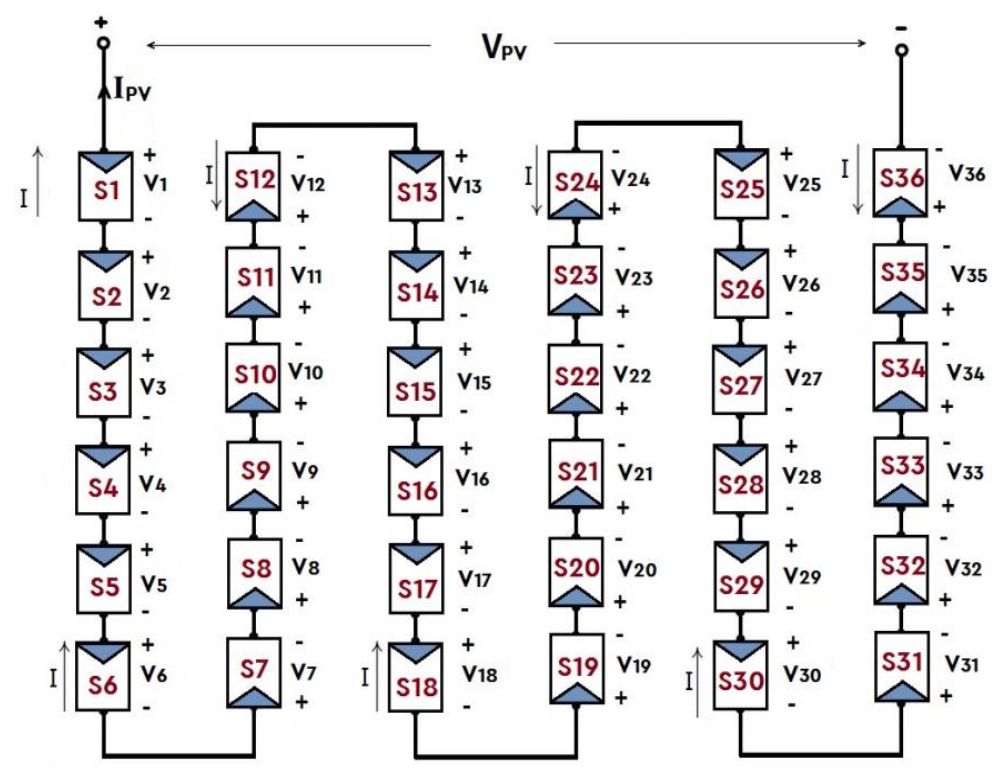

Figure 5. $6 \times 6$ Simple Series configuration

In a series connection, the same current flowing through the 36 modules in the array. Apply KVL for one closed loop in the Simple Series topology and the KVL equation is written as,

$$
\sum_{n=1}^{36} V_{n}=V_{P V}
$$

where $\mathrm{n}$ is the number of modules in an array configuration.

It is noted that a $6 \times 6$ array of SS connection has 36 module voltages and the one array current.

$$
\text { i.e., } \quad \begin{aligned}
\boldsymbol{V}_{\boldsymbol{P V}} & =V_{1}+V_{2}+\cdots . .+V_{36} & ---(6) \\
\boldsymbol{I}_{\boldsymbol{P V}} & =I & ---(7)
\end{aligned}
$$

(ii) Simple Parallel Configuration

The simple parallel configuration is shown in Figure 6. Where, $I_{P V}$ and $V_{P V}$ are the array current and voltage.

In a parallel configuration, all the modules have the same voltage (In any parallel, the circuit voltages are equal), i.e., $\mathrm{V}_{1}=\mathrm{V}_{2}=\ldots \ldots \ldots=\mathrm{V}_{36}=\mathrm{V}$ as shown in Figure 6 and different currents. Apply KCL at different nodes, then

$$
\sum_{n=1}^{36} I_{n}=I_{P V}
$$




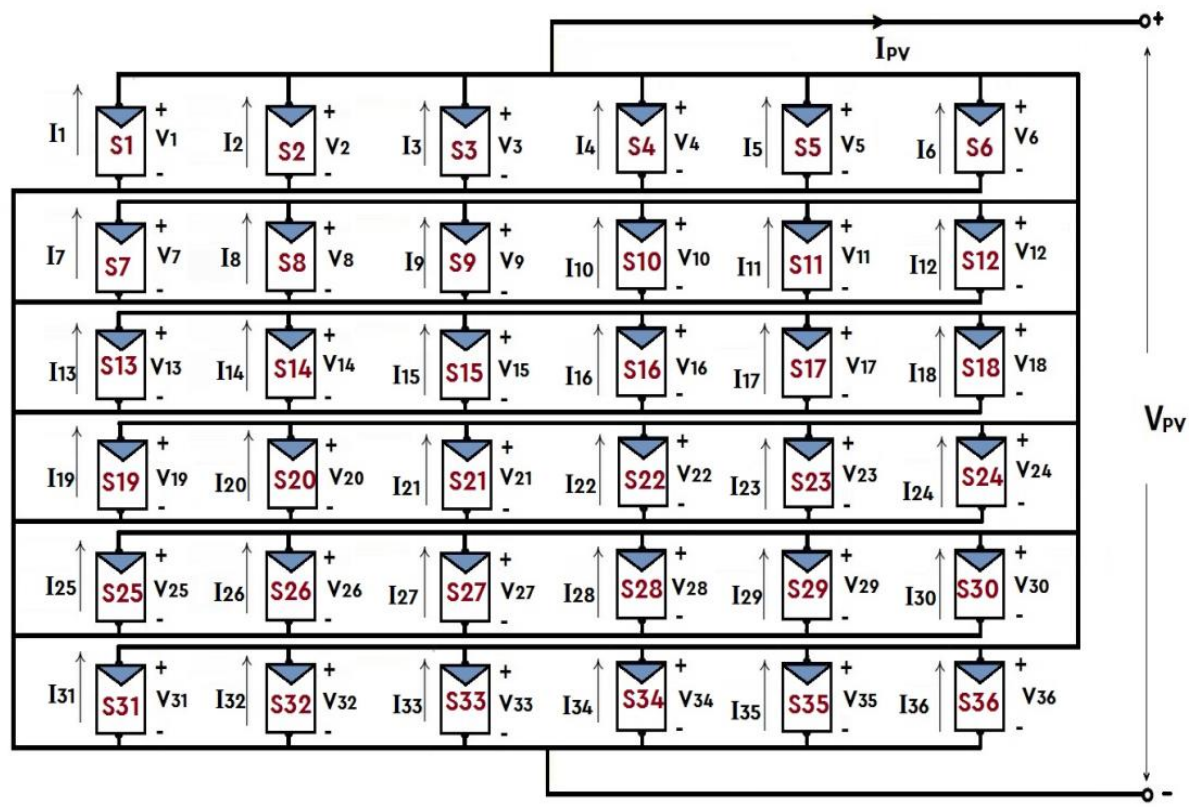

Figure 6. $6 \times 6$ Simple Parallel configuration

Where $\mathbf{n}$ is the number of modules in an array configuration. It is noted that a $6 \times 6$ array of parallel connection has 36 module currents and the one array voltage.

i.e.,

$$
\begin{gathered}
\boldsymbol{V}_{\boldsymbol{P V}}=V_{1}=V_{2}=\cdots=V_{36}=\boldsymbol{V} \\
\boldsymbol{I}_{\boldsymbol{P V}}=I_{1}+I_{2}+\cdots \ldots \ldots+I_{36}
\end{gathered}
$$$$
---(9)
$$

\section{(iii) Series-Parallel Configuration}

The circuit of Series-Parallel (S-P) configuration of modules in an array is shown in Figure 7. This topology has four parallel strings, and each contains nine seriesconnected modules.

The total array current $I_{P V}$ is equal to the sum of the six-string currents.

i.e.,

$$
\boldsymbol{I}_{\boldsymbol{P V}}=I_{1}+I_{2}+I_{3}+I_{4}+I_{5}+I_{6}
$$

The six parallel string voltages are equal to the array voltage. Apply KVL at parallel strings, then the equations are given by,

$$
\sum_{n=1}^{6} V_{n}=\sum_{n=7}^{12} V_{n}=\sum_{n=13}^{18} V_{n}=\sum_{n=19}^{24} V_{n}=\sum_{n=25}^{30} V_{n}=\sum_{n=31}^{36} V_{n}=\boldsymbol{V}_{\boldsymbol{P V}}
$$

The SP configuration has 36 module voltages and four-string currents. SP configuration voltages and currents in $1^{\text {st }}, 2^{\text {nd }}, 3^{\text {rd }}, 4^{\text {th }}, 5^{\text {th }}, 6^{\text {th }}$ columns are $V_{1}$ to $V_{6}, V_{7}$ to $\mathrm{V}_{12}, \mathrm{~V}_{13}$ to $\mathrm{V}_{18}, \mathrm{~V}_{19}$ to $\mathrm{V}_{24}, \mathrm{~V}_{25}$ to $\mathrm{V}_{30}, \mathrm{~V}_{31}$ to $\mathrm{V}_{36}$ and $\mathrm{I}_{1}, \mathrm{I}_{2}, \mathrm{I}_{3}, \mathrm{I}_{4}, \mathrm{I}_{5}, \mathrm{I}_{6}$, respectively, which are shown in Figure 7. 


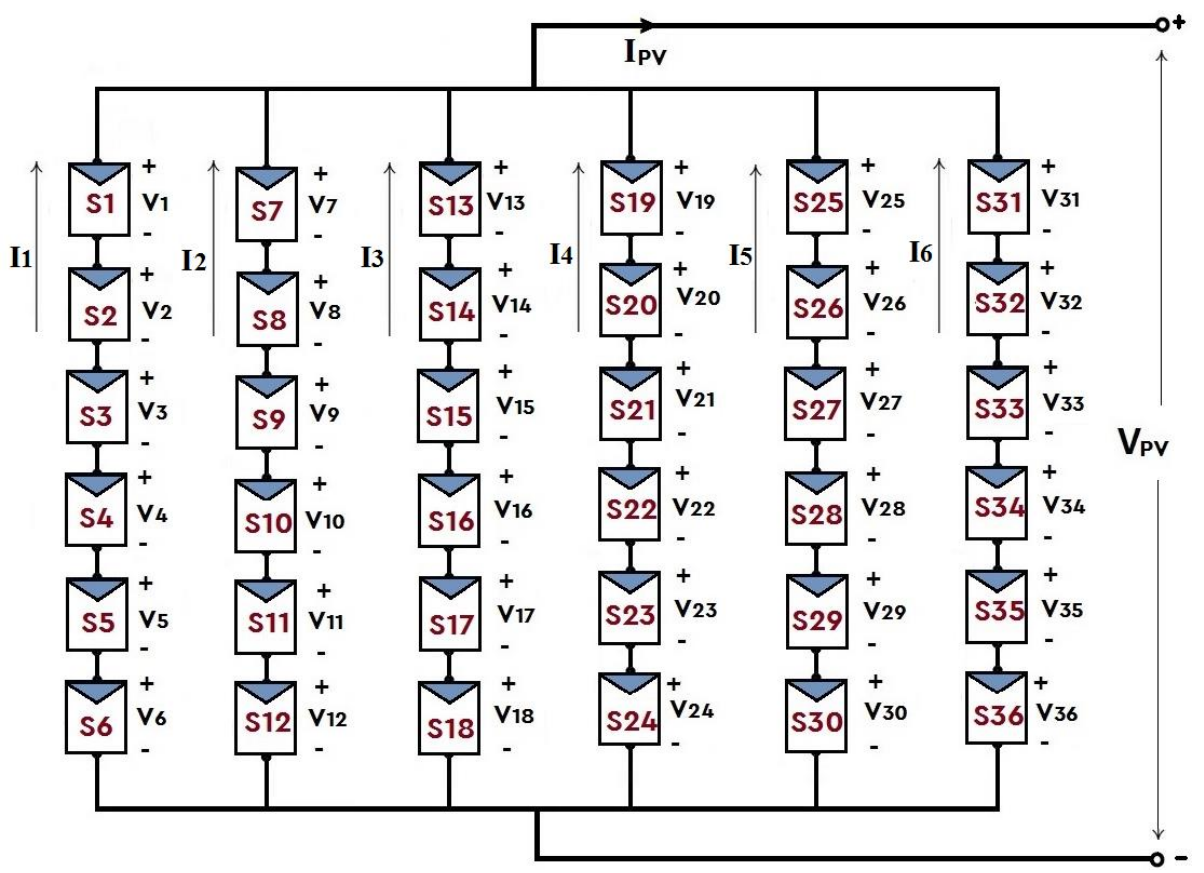

Figure 7. $6 \times 6$ Series-Parallel configuration

\section{(iv) Total-Cross-Tied Configuration}

The solar PV array with TCT configuration is shown in Figure 8. The voltage of 6 parallel modules at the $\mathrm{m}^{\text {th }}$ row is $\mathrm{V}_{\mathrm{m}}$. where,

$$
m=\left\{\begin{array}{cc}
n & \text { for } 1 \leq n \leq 6 \\
n-6 & \text { for } 7 \leq n \leq 12 \\
n-12 & \text { for } 13 \leq n \leq 18 \\
n-18 & \text { for } 19 \leq n \leq 24 \\
n-24 & \text { for } 25 \leq n \leq 30 \\
n-30 & \text { for } 30 \leq n \leq 36
\end{array}\right.
$$

The array voltage $V_{P V}$ is equal to the sum of six rows of individual module voltages:

$$
\begin{aligned}
& \boldsymbol{V}_{\mathbf{P V}}=\sum_{m=1}^{6} V_{m} \\
& V_{\mathrm{PV}}=V_{1}+V_{2}+V_{3}+V_{4}+V_{5}+V_{6}
\end{aligned}
$$

Where,

$$
\begin{aligned}
& \boldsymbol{V}_{1}=\mathrm{v}_{1}=\mathrm{v}_{7}=\mathrm{v}_{13}=\mathrm{v}_{19}=\mathrm{v}_{25}=\mathrm{v}_{31} \\
& \boldsymbol{V}_{\mathbf{2}}=\mathrm{v}_{2}=\mathrm{v}_{8}=\mathrm{v}_{14}=\mathrm{v}_{20}=\mathrm{v}_{21}=\mathrm{v}_{32} \\
& \boldsymbol{V}_{\mathbf{3}}=\mathrm{v}_{3}=\mathrm{v}_{9}=\mathrm{v}_{15}=\mathrm{v}_{21}=\mathrm{v}_{22}=\mathrm{v}_{33} \\
& \boldsymbol{V}_{\mathbf{4}}=\mathrm{v}_{4}=\mathrm{v}_{10}=\mathrm{v}_{16}=\mathrm{v}_{22}=\mathrm{v}_{23}=\mathrm{v}_{34} \\
& \boldsymbol{V}_{\mathbf{5}}=\mathrm{v}_{5}=\mathrm{v}_{11}=\mathrm{v}_{17}=\mathrm{v}_{23}=\mathrm{v}_{24}=\mathrm{v}_{35} \\
& \boldsymbol{V}_{\mathbf{6}}=\mathrm{v}_{6}=\mathrm{v}_{12}=\mathrm{v}_{18}=\mathrm{v}_{24}=\mathrm{v}_{25}=\mathrm{v}_{36}
\end{aligned}
$$


Apply KCL at nodes 1 to 5, as shown in Figure 8.

$$
\sum_{m=0}^{5}\left(I_{6 . m+q}-I_{6 \cdot m+(q+1)}\right)=0 ; q=1,2,3,4,5 ;
$$

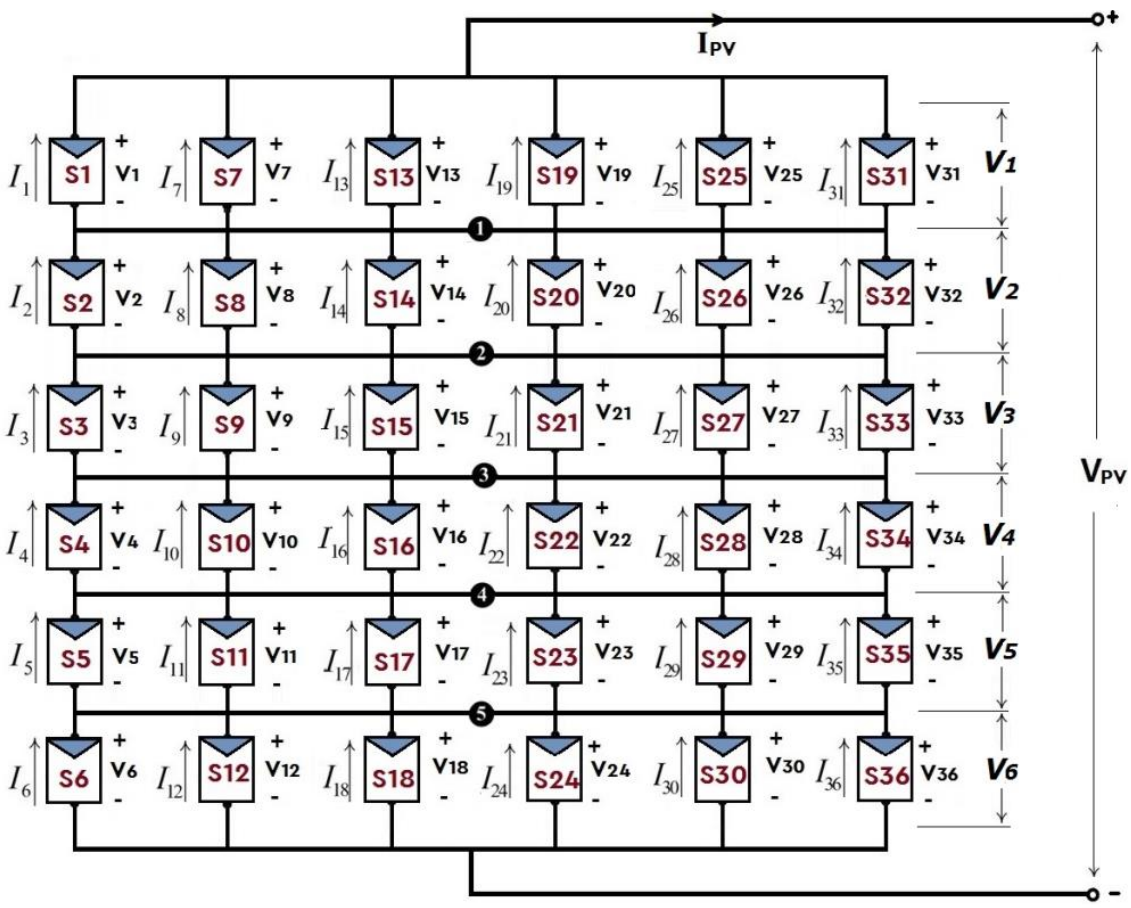

Figure 8. $6 \times 6$ Total-Cross-Tied configuration

The TCT topology has 36 module currents and 6 module voltages, as shown in Figure 8 . TCT configuration has currents in $1^{\text {st }}, 2^{\text {nd }}, 3^{\text {rd }}, 4^{\text {th }}, 5^{\text {th }}, 6^{\text {th }}$ columns, which are $I_{1}$ to $\mathrm{I}_{6}, \mathrm{I}_{7}$ to $\mathrm{I}_{12}, \mathrm{I}_{13}$ to $\mathrm{I}_{18}, \mathrm{I}_{19}$ to $\mathrm{I}_{24}, \mathrm{I}_{25}$ to $\mathrm{I}_{30}, \mathrm{I}_{31}$ to $\mathrm{I}_{36}$, and voltages in $1^{\text {st }}$ row to $6^{\text {th }}$ rows are $V_{1}$ to $\mathrm{V}_{6}$.

\section{(v) Bridge-linked Connection Configuration}

The solar PV array with B-L configuration is shown in Figure 9. The module currents and voltages are $I_{m}$ and $V_{p}$, respectively. The subscripts $m, p$ are related to module number $\mathrm{n}$, where,

$m=\left\{\begin{array}{cc}1 & \text { for } n=1,2 \\ 2 & \text { for } \mathrm{n}=3,4 \\ 3 & \text { for } \mathrm{n}=5,6 \\ \mathrm{n}-3 ; & \text { for } \mathrm{7} \leq \mathrm{n} \leq 30 ; \\ 28 & \text { for } \mathrm{n}=31,32 \\ 29 & \text { for } \mathrm{n}=33,34 \\ 30 & \text { for } \mathrm{n}=35,36 ;\end{array} \quad p=\left\{\begin{array}{cr}\mathrm{n} & \text { for } 1 \leq \mathrm{n} \leq 12 \\ \mathrm{n}-6 & \text { for } \mathrm{n}=13,18 \\ \mathrm{n}-1 & \text { for } 14 \leq \mathrm{n} \leq 17 \\ \mathrm{n}-2 & \text { for } 19 \leq \mathrm{n} \leq 24 \\ \mathrm{n}-8 & \text { for } \mathrm{n}=25,30 \\ \mathrm{n}-4 & \text { for } \mathrm{n}=31,36\end{array}\right.\right.$ 
In this BL type connection topology, 30 module currents and 32 voltages across modules. Figure 9 shows the 12 nodes in the BL topology.

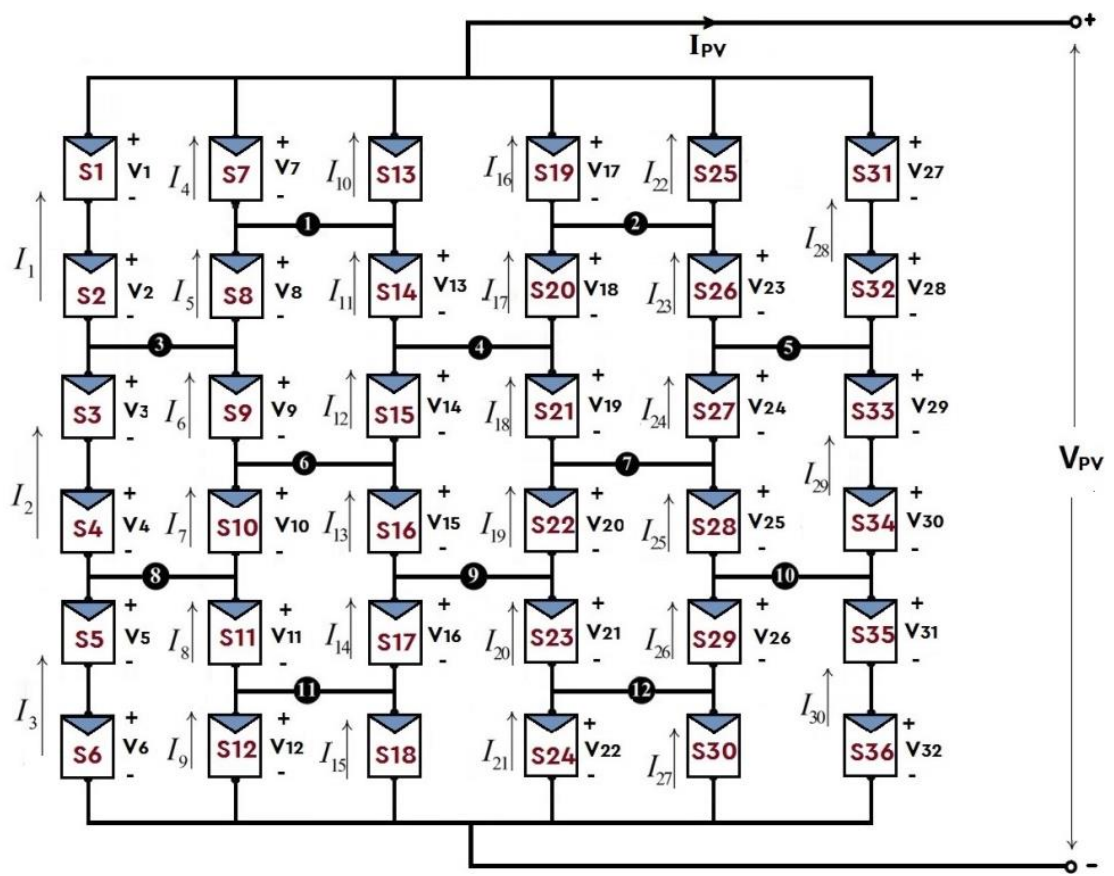

Figure 9. $6 \times 6$ Bridge-Linked configuration

The node numbers 3 and 8 at the left column, apply the KCL at node points:

$$
I_{m}+I_{q}-I_{m+1}-I_{q+1}=0 ; m=1,2
$$

where the subscript $q$ is related to $m$ by,

$$
q= \begin{cases}5 & \text { for } m=1 \\ 7 & \text { for } m=2\end{cases}
$$

Similarly, apply KCL for the nodes $1,6,11$ between $2^{\text {nd }} \& 3^{\text {rd }}$ column and nodes 4,9 between $3^{\text {rd }} \& 4^{\text {th }}$ columns,

$$
I_{m}+I_{m+6}-I_{m+1}-I_{m+7}=0 ; m=4,6,8,11,13,16,18,20 \quad---(16)
$$

For the node numbers 5,10 between $5^{\text {th }}$ and $6^{\text {th }}$ columns, apply the KCL at node points:

$$
I_{m}+I_{q}-I_{m+1}-I_{q+1}=0 ; m=23,25
$$

in which the subscripts $q$ and $m$ relate to each other by,

$$
q= \begin{cases}28 & \text { for } m=23 \\ 29 & \text { for } m=25\end{cases}
$$


Figure 9 shows the loops and each loop contains four modules, apply KVL for the loops:

$$
\begin{array}{lr}
V_{p}+V_{p+1}-V_{p+6}-V_{p+7}=0 ; & p=1,3,5 \\
V_{p}+V_{p+1}-V_{p+5}-V_{p+6}=0 ; & p=8,10 \\
V_{p+6}+V_{p}-V_{p+10}-V_{p+11}=0 ; & p=7,17 \\
V_{p}+V_{p+1}-V_{p+5}-V_{p+6}=0 ; & p=14,18,20,24 \\
V_{p+4}+V_{p}-V_{p+9}-V_{p+10}=0 ; & p=12,22
\end{array}
$$

Finally, apply the KVL for six modules loop in the $1^{\text {st }}$ column is given by

$$
\sum_{p=1}^{6} V_{p}=V_{P V}
$$

The $6 \times 6 \mathrm{BL}$ configuration has 32 voltages and 30 currents which are shown in Figure 9 . BL configuration voltages and currents in $1^{\text {st }}, 2^{\text {nd }}, 3^{\text {rd }}, 4^{\text {th }}, 5^{\text {th }}, 6^{\text {th }}$ columns are $V_{1}$ to $\mathrm{V}_{6}, \mathrm{~V}_{7}$ to $\mathrm{V}_{12}, \mathrm{~V}_{13}$ to $\mathrm{V}_{16}, \mathrm{~V}_{17}$ to $\mathrm{V}_{22}, \mathrm{~V}_{23}$ to $\mathrm{V}_{26}, \mathrm{~V}_{27}$ to $\mathrm{V}_{32}$ and $\mathrm{I}_{1}$ to $\mathrm{I}_{3}, \mathrm{I}_{4}$ to $\mathrm{I}_{9}, \mathrm{I}_{10}$ to $\mathrm{I}_{15}, \mathrm{I}_{16}$ to $\mathrm{I}_{21}, \mathrm{I}_{22}$ to $\mathrm{I}_{27}, \mathrm{I}_{28}$ to $\mathrm{I}_{30}$, respectively.

\section{(vi) Honey-Comb Connection Configuration}

The PV array with HC connection configuration is shown in Figure 10. The module currents and voltages are $I_{m}$ and $V_{p}$, respectively. The subscripts $m, p$ are related to module number $\mathrm{n}$.

where,

$$
m=\left\{\begin{array}{cc}
1 & \text { for } \mathrm{n}=1 \\
2 & \text { for } \mathrm{n}=2,3,4 \\
3 & \text { for } \mathrm{n}=5 \\
4 & \text { for } \mathrm{n}=6 \\
\mathrm{n}-2 & \text { for } 7 \leq \mathrm{n} \leq 31 \\
30 & \text { for } \mathrm{n}=32,33,34 \\
31 & \text { for } \mathrm{n}=35 \\
32 & \text { for } \mathrm{n}=36
\end{array} ; p=\left\{\begin{array}{c}
\mathrm{n} ; \text { for } 1 \leq \mathrm{n} \leq 6 \\
1 ; \text { for } \mathrm{n}=7 \\
\mathrm{n}-1 ; \text { for } \mathrm{n}=8,9,10 \\
5 ; \text { for } \mathrm{n}=11 \\
6 ; \text { for } \mathrm{n}=12 \\
\mathrm{n}-3 ; \text { for } \mathrm{n}=13,14 \\
8 ; \text { for } \mathrm{n}=15 \\
\mathrm{n}-4 ; \text { for } \mathrm{n}=16,17,18 \\
10 ; \text { for } \mathrm{n}=19
\end{array} ; p=\left\{\begin{array}{c}
\mathrm{n}-5 ; \text { for } \mathrm{n}=20,21,22 \\
13 ; \text { for } \mathrm{n}=23 \\
14 ; \text { for } \mathrm{n}=24 \\
\mathrm{n}-7 ; \text { for } \mathrm{n}=25,26 \\
16 ; \text { for } \mathrm{n}=27 \\
\mathrm{n}-8 ; \text { for } \mathrm{n}=28,29,30 \\
18 ; \text { for } \mathrm{n}=31 \\
\mathrm{n}-9 ; \text { for } \mathrm{n}=32,33,34 \\
21 ; \text { for } \mathrm{n}=35 \\
22 ; \text { for } \mathrm{n}=36
\end{array}\right.\right.\right.
$$

In the $\mathrm{HC}$ connection type topology, the total number of nodes is 13 . Apply KCL for each node,

$$
I_{m}+I_{q}-I_{m+1}-I_{q+1}=0 ; \quad m=1,2,3,6,7,11,14,15,18,19,23,26,27
$$

and the subscript $q$ is related to $m$ given by

$$
q=\left\{\begin{array}{ll}
5 & \mathrm{~m}=1 \\
8 & \mathrm{~m}=2 \\
9 & \mathrm{~m}=3 \\
12 & \mathrm{~m}=6
\end{array} ; q=\left\{\begin{array}{cc}
13 & \mathrm{~m}=7 \\
17 & \mathrm{~m}=11 \\
20 & \mathrm{~m}=14 \\
21 & \mathrm{~m}=15
\end{array} ; q= \begin{cases}24 & \mathrm{~m}=18 \\
25 & \mathrm{~m}=19 \\
29 & \mathrm{~m}=23 \\
30 & \mathrm{~m}=26 \\
31 & \mathrm{~m}=27\end{cases}\right.\right.
$$




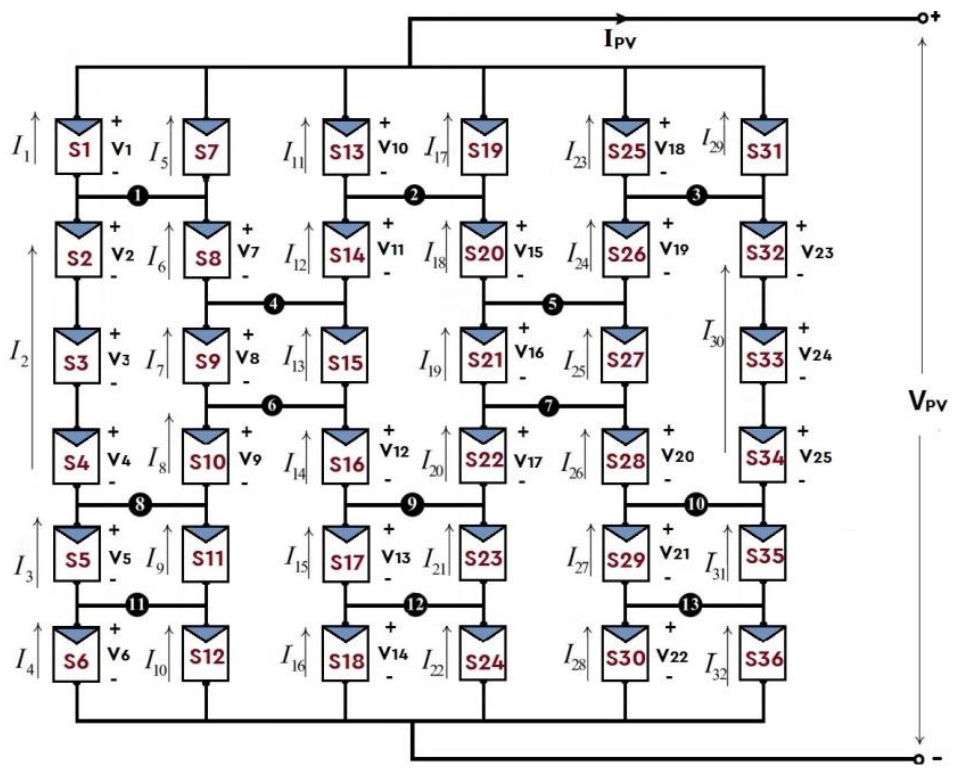

Figure 10. $6 \times 6$ Honey-Comb configuration

Then apply KVL to six or four modules in a loop,

$$
\begin{aligned}
& V_{p}+V_{p+1}+V_{p+2}-V_{q}-V_{q+1}-V_{q+2}=0 ; \quad(\boldsymbol{p}, \boldsymbol{q})=(2,7) \\
& V_{q}+V_{p}-V_{p+3}-V_{p+4}=0 ; \quad(p, q)=(7,1) \&(15,10) \\
& V_{p}+V_{p-3}+V_{p+1}-V_{p+4}-V_{p+5}-V_{p+6}=0 ; \quad p=11,19 \\
& V_{p}+V_{p-4}+V_{p-3}-V_{q}-V_{q+1}-V_{q+2}=0 ; \quad(p, q)=(9,12) \&(17,20)
\end{aligned}
$$

Finally, apply KVL for the six modules loop in the left column is given as,

$$
\sum_{n=1}^{6} V_{n}=\boldsymbol{V}_{\boldsymbol{P V}}
$$

In $6 \times 6, \mathrm{HC}$ configuration has 25 module voltages and 32 currents, as shown in Figure 10 . HC configuration has voltages and currents in $1^{\text {st }}, 2^{\text {nd }}, 3^{\text {rd }}, 4^{\text {th }}, 5^{\text {th }}, 6^{\text {th }}$ columns are $V_{1}$ to $V_{6}, V_{7}$ to $V_{9}, V_{10}$ to $V_{14}, V_{15}$ to $V_{17}, V_{18}$ to $V_{22}, V_{23}$ to $V_{25}$ and $I_{1}$ to $I_{4}, I_{5}$ to $I_{10}$, $I_{11}$ to $I_{16}, I_{17}$ to $I_{22}, I_{23}$ to $I_{28}, I_{29}$ to $I_{32}$, respectively.

Mathematical analysis of $6 \times 6 \mathrm{PV}$ connection configurations is tabulated in Table 1. Where $P_{P V}, V_{P V}$ and $I_{P V}$ are the output power, voltage and current of the SPV array respectively, $\mathrm{V}$ and $\mathrm{I}$ are the voltage and current output of a single PV module respectively. 


\subsection{Generation of Power Across the TCT array configuration}

In this section, the power generation of SPV array with TCT configuration is discussed and output voltage, current and power of an array are theoretically calculated.

The current $I$ generated by a single solar module at any irradiance $\mathrm{G}$ is given as,

$$
\boldsymbol{I}=\left(\frac{G}{G_{o}}\right) \cdot I_{m}
$$

where $G$ is irradiance at shading condition, and $G_{0}$ is the standard irradiance of 1000 $\mathrm{W} / \mathrm{m}^{2}$. If the solar module receives full irradiance, the output current of the module is more and vice-versa.

The PV array voltage $V_{P V}$ is given as the summation of individual module voltages in the rows in an array, i.e.,

$$
\boldsymbol{V}_{\boldsymbol{P V}}=\sum_{p=1}^{n} V_{m p}
$$

where $V_{m p}$ is the maximum module voltage at $\mathrm{p}^{\text {th }}$ row. In a $6 \times 6$ TCT SPV array configuration, number of rows are 6, each row voltage is $\mathrm{Vm}$ ( the maximum module voltage), so the total voltage of an array is equal to the sum of row voltage. By neglecting the voltage drop across diodes, the SPV array voltage is given as,

$$
\boldsymbol{V}_{\boldsymbol{P V}}=V_{m 1}+V_{m 2}+V_{m 3}+V_{m 4}+V_{m 5}+V_{m 6}
$$

where, $V_{m 1}$ to $V_{m 6}$ are the maximum voltage of parallel connected modules in rows. Each row has 6 number of modules are connected in parallel and the row voltage is equal to $V_{m}$ (total voltage is same as individual voltages in parallel connection), then

$$
\boldsymbol{V}_{\boldsymbol{P V}}=6 V_{m}
$$

By applying the Kirchhoff's current law, the output current of an TCT SPV array configuration ( current across each node in an array) is given by,

$$
\boldsymbol{I}_{\boldsymbol{P V}}=\sum_{q=1}^{n}\left(I_{p q}-I_{(p+1) q}\right)=0 ; \quad \text { where }, p=1,2, \ldots,(n-1)---(26)
$$

where, $\mathbf{p}$ and $\mathbf{q}$ are the number of rows and columns of the SPV array.

For a $6 \times 6$ solar PV array TCT configuration, the number of rows is six are connected in series and number of modules per row is 6 are connected in parallel. The total array current is the sum of six number of module currents in each row given as,

$$
\boldsymbol{I}_{\boldsymbol{P V}}=I_{m 1}+I_{m 2}+I_{m 3}+I_{m 4}+I_{m 5}+I_{m 6}
$$

where, $I_{m 1}$ to $I_{m 6}$ are the maximum current of parallel connected modules in rows. Each row has 6 number of modules are connected in parallel and maximum current of each 
module is equal to $I_{m}$ (total current is the sum of individual module currents in parallel connection), then

$$
\boldsymbol{I}_{\boldsymbol{P V}}=6 I_{m}
$$

where $\mathbf{I}_{\mathbf{m}}$ is the maximum generated current of each PV module in an array. Under un-shaded conditions, the power output of a $6 \times 6$ Solar PV TCT array is given as,

$$
\boldsymbol{P}_{\boldsymbol{P V}}=V_{P V} \cdot I_{P V}=6 V_{m} \cdot 6 I_{m}=36 V_{m} \cdot I_{m}
$$

Table 1. Parameters $(\mathrm{V}, \mathrm{I}$ and $\mathrm{P})$ of a $6 \times 6$ SPV Array Topologies

\begin{tabular}{|l|c|c|c|}
\hline \multirow{2}{*}{ Configurations } & $\begin{array}{c}\text { Array Voltage } \\
V_{P V}(\mathrm{~V})\end{array}$ & $\begin{array}{c}\text { Array Current } \\
I_{P V}(\mathrm{~A})\end{array}$ & $\begin{array}{c}\text { Array Power } \\
P_{P V}(\mathrm{~W})\end{array}$ \\
\cline { 2 - 4 } Simple Series & $V_{P V}=\sum_{n=1}^{36} V_{n}=36 \mathrm{~V}$ & $I_{P V}=I$ & $P_{P V}=36 \mathrm{VI}$ \\
\hline Simple Parallel & $V_{P V}=V$ & $I_{P V}=\sum_{n=1}^{36} I_{n}=36 I$ & $P_{P V}=36 \mathrm{VI}$ \\
\hline Series-Parallel & $V_{P V}=\sum_{n=1}^{6} V_{n}=6 \mathrm{~V}$ & $I_{P V}=\sum_{n=1}^{6} I_{n}=6 I$ & $P_{P V}=36 \mathrm{VI}$ \\
\hline Total-Cross- & $V_{P V}=\sum_{n=1}^{6} V_{n}=6 V$ & $I_{P V}=\sum_{n=1}^{6} I_{n}=6 I$ & $P_{P V}=36 \mathrm{VI}$ \\
\hline Bied & $V_{P V}=\sum_{n=1}^{6} V_{n}=6 V$ & $\begin{array}{l}I_{P V} \\
=I_{1}+I_{4}+I_{10}+I_{16} \\
+I_{22}+I_{28}=6 I\end{array}$ & $P_{P V}=36 \mathrm{VI}$ \\
\hline Honey-Comb & $V_{P V}=\sum_{n=1}^{6} V_{n}=6 \mathrm{~V}$ & $\begin{array}{l}I_{P V} \\
=I_{1}+I_{5}+I_{11}+I_{17} \\
+I_{23}+I_{29}=6 I\end{array}$ & $P_{P V}=36 \mathrm{VI}$ \\
\hline
\end{tabular}

\section{Mathematical Analysis of Partial Shaded SPV Array with TCT Configurations}

5.1 Row Currents and Output Powers of the SPV Array with TCT topology

Figure 12 shows the partially shaded modules in the $6 \times 6 \mathrm{PV}$ array with TCT configurations [13-14]. For mathematical analysis of $6 \times 6$, TCT configuration calculates the currents in each row, array voltage, and array power [12]. The row currents are given as

$$
\begin{gathered}
I_{R p}=\sum_{n=1}^{6} S_{p n} I_{m}=S_{p 1} I_{m}+S_{p 2} I_{m}+S_{p 3} I_{m}+S_{p 4} I_{m}+S_{p 5} I_{m}+S_{p 6} I_{m}---(29) \\
\text { where, } S_{p 1}=\left(\frac{G_{p 1}}{G_{o}}\right), S_{p 2}=\left(\frac{G_{p 2}}{G_{o}}\right), S_{p 3}=\left(\frac{G_{p 3}}{G_{o}}\right), S_{p 4}=\left(\frac{G_{p 4}}{G_{o}}\right), S_{p 5}=\left(\frac{G_{p 5}}{G_{o}}\right), S_{p 6}=\left(\frac{G_{p 6}}{G_{o}}\right)--(30)
\end{gathered}
$$


where $p$ is row number, $G_{0}$ is the standard irradiance of $1000 \mathrm{~W} / \mathrm{m}^{2}, G_{p 1}$ is the $\mathrm{P}^{\text {th }}$ row and $1^{\text {st }}$ column irradiance value in $\mathrm{W} / \mathrm{m}^{2}$.

The $1^{\text {st }}$-row current is given as,

$$
\begin{gathered}
\boldsymbol{I}_{\boldsymbol{R} \mathbf{1}}=\sum_{n=1}^{6} S_{1 n} I_{m}=S_{11} I_{m}+S_{12} I_{m}+S_{13} I_{m}+S_{14} I_{m}+S_{15} I_{m}+S_{16} I_{m} \\
\text { Where, } S_{11}=\left(\frac{G_{11}}{G_{o}}\right), S_{12}=\left(\frac{G_{12}}{G_{o}}\right), S_{13}=\left(\frac{G_{13}}{G_{o}}\right), S_{14}=\left(\frac{G_{14}}{G_{o}}\right), S_{15}=\left(\frac{G_{15}}{G_{o}}\right), S_{16}=\left(\frac{G_{16}}{G_{o}}\right)
\end{gathered}
$$

The $2^{\text {nd }}, 3^{\text {rd }}, 4^{\text {th }}, 5^{\text {th }}$, and $6^{\text {th }}$-row currents are given as,

$$
\begin{aligned}
& \boldsymbol{I}_{\boldsymbol{R} \mathbf{2}}=\sum_{n=1}^{6} S_{2 n} I_{m}=S_{21} I_{m}+S_{22} I_{m}+S_{23} I_{m}+S_{24} I_{m}+S_{25} I_{m}+S_{26} I_{m}---(32) \\
& \boldsymbol{I}_{\boldsymbol{R} \mathbf{3}}=\sum_{n=1}^{6} S_{3 n} I_{m}=S_{31} I_{m}+S_{32} I_{m}+S_{33} I_{m}+S_{34} I_{m}+S_{35} I_{m}+S_{36} I_{m}---(33) \\
& \boldsymbol{I}_{\boldsymbol{R} \mathbf{4}}=\sum_{n=1}^{6} S_{4 n} I_{m}=S_{41} I_{m}+S_{42} I_{m}+S_{43} I_{m}+S_{44} I_{m}+S_{45} I_{m}+S_{46} I_{m}--(34) \\
& \boldsymbol{I}_{\boldsymbol{R} \mathbf{5}}=\sum_{n=1}^{6} S_{5 n} I_{m}=S_{51} I_{m}+S_{52} I_{m}+S_{53} I_{m}+S_{54} I_{m}+S_{55} I_{m}+S_{56} I_{m}---(35) \\
& \boldsymbol{I}_{\boldsymbol{R} \mathbf{6}}=\sum_{n=1}^{6} S_{6 n} I_{m}=S_{61} I_{m}+S_{62} I_{m}+S_{63} I_{m}+S_{64} I_{m}+S_{65} I_{m}+S_{66} I_{m}---(36)
\end{aligned}
$$

Since the currents are different in each row, so two or more peaks occur in output characteristics (P-V curves). In the TCT SPV array configuration, the global MPP, is the product of voltage and current of each row. The array current depends on the irradiance, and the array voltage is the same for all the rows by neglecting the voltage drop across the diodes. Solar PV array output voltage and power are given as,

$$
\begin{aligned}
& \boldsymbol{V}_{\boldsymbol{P V}}=6 V_{m} \\
& \boldsymbol{P}_{\boldsymbol{P V}}=V_{P V} \cdot I_{P V}=36 \cdot V_{P V} \cdot I_{P V}
\end{aligned}
$$$$
----(37)
$$

The theoretical calculations of current, voltage, and power of TCT array topology are tabulated in Table 2.

\subsection{Generation and Location of Global MPP for Shaded PV Array TCT Topology}

The SPV array with TCT configuration under various shading cases are shown in Figure 12 [13]. For mathematical analysis of partially shaded conventional TCT configurations [15], four partial shading patterns are shown in Figure 11 and the irradiance of shaded panels is $500 \mathrm{~W} / \mathrm{m}^{2}$ are considered. There are mainly, 
(a) Short Narrow shading (SNS)

(b) Short Wide shading (SWS)

(c) Long Narrow shading (SNS)

(d) Long Wide shading (SNS)

(e) Un-shaded Case (U)

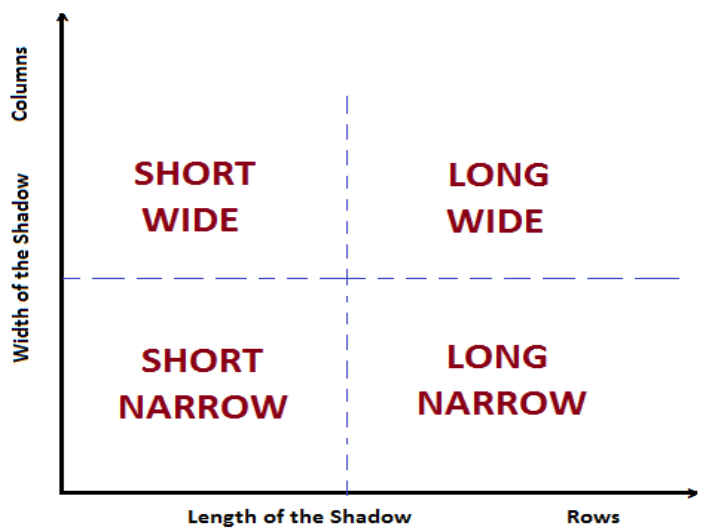

Figure 11. Types of shading cases

(a) Short Narrow Shading (SNS)

The short narrow type of shading scenario is observed in Figure 12(a). For formulating the location of Global Maximum Power Point (GMPP) in the output P-V characteristics theoretically, first calculate the currents in each row of the SPV array. From Figure 12(a), the $1^{\text {st }}$-row current is calculated from Equation 31,

$$
\boldsymbol{I}_{\boldsymbol{R} 1}=\left(\frac{G_{11}}{G_{o}}\right) I_{m}+\left(\frac{G_{12}}{G_{o}}\right) I_{m}+\left(\frac{G_{13}}{G_{o}}\right) I_{m}+\left(\frac{G_{14}}{G_{o}}\right) I_{m}+\left(\frac{G_{15}}{G_{o}}\right) I_{m}+\left(\frac{G_{16}}{G_{o}}\right) I_{m}
$$

where, $G_{11}=G_{12}=G_{13}=G_{14}=G_{15}=G_{16}=$ irradiances at shading and $G_{0}$ is the standard irradiance of $1000 \mathrm{~W} / \mathrm{m}^{2}$.

From Figure 12(a): In short narrow shading, PV panels in $1^{\text {st }}, 2^{\text {nd }}$ and $3^{\text {rd }}$ rows are under full uniform irradiation level of $1000 \mathrm{~W} / \mathrm{m}^{2}$, while the remaining rows are under different irradiance of $500 \mathrm{~W} / \mathrm{m}^{2}$. The current generated by the $1^{\text {st }}, 2^{\text {nd }}$, and $3^{\text {rd }}$ rows are calculated as follows:

$$
\boldsymbol{I}_{\boldsymbol{R} \mathbf{1}}=\boldsymbol{I}_{\boldsymbol{R} \mathbf{2}}=\boldsymbol{I}_{\boldsymbol{R} \mathbf{3}}=\left(\frac{1000}{1000}\right) I_{m}+\left(\frac{1000}{1000}\right) I_{m}+\left(\frac{1000}{1000}\right) I_{m}+\left(\frac{1000}{1000}\right) I_{m}+\left(\frac{1000}{1000}\right) I_{m}+\left(\frac{1000}{1000}\right) I_{m}=6 I_{m}---(\boldsymbol{i})
$$

Modules in row $4^{\text {th }}, 5^{\text {th }}$ and $6^{\text {th }}$ are shaded and the corresponding row currents are given by,

$$
\boldsymbol{I}_{\boldsymbol{R} 4}=\boldsymbol{I}_{\boldsymbol{R} 5}=\boldsymbol{I}_{\boldsymbol{R} \boldsymbol{6}}=\left(\frac{1000}{1000}\right) I_{m}+\left(\frac{1000}{1000}\right) I_{m}+\left(\frac{1000}{1000}\right) I_{m}+\left(\frac{500}{1000}\right) I_{m}+\left(\frac{500}{1000}\right) I_{m}+\left(\frac{500}{1000}\right) I_{m}=4.5 I_{m}--(i \boldsymbol{i})
$$


From the row currents given in $i$ and $i i$, it is observed that the currents in different rows are changing from $4.5 I_{m}$ to $6 I_{m}$. Due to these varying currents, multiple peaks are generated in the output characteristics.

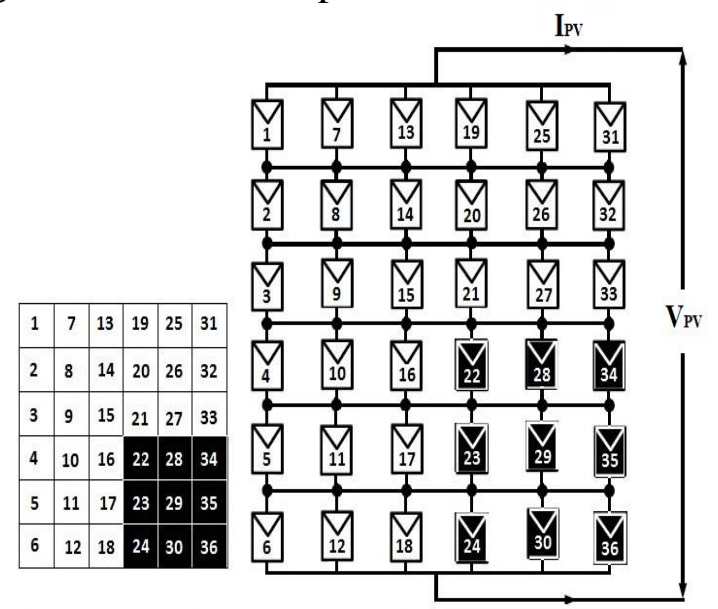

(a) Short Narrow Shading (SNS) on Modules of 6x6 Solar PV Array in TCT Configuration

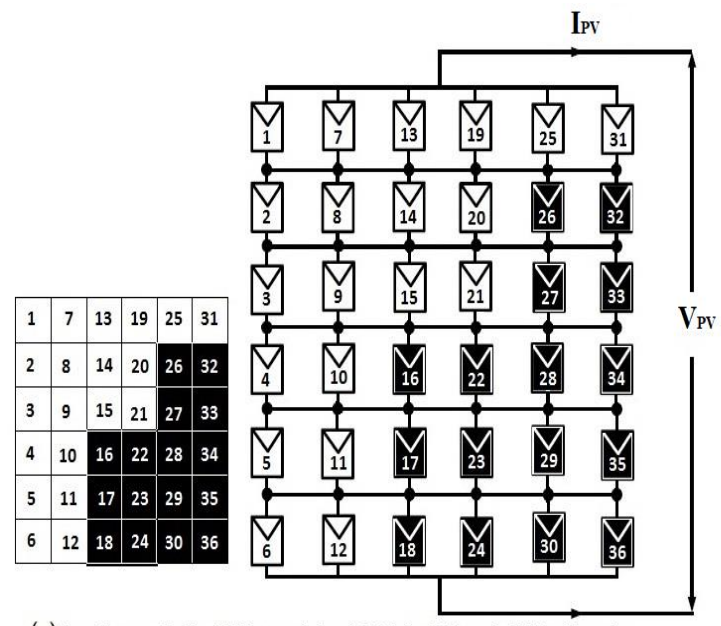

(c) Long Narrow Shading (LNS) on modules of $6 \times 6$ Solar PV Array in TCT Configuration

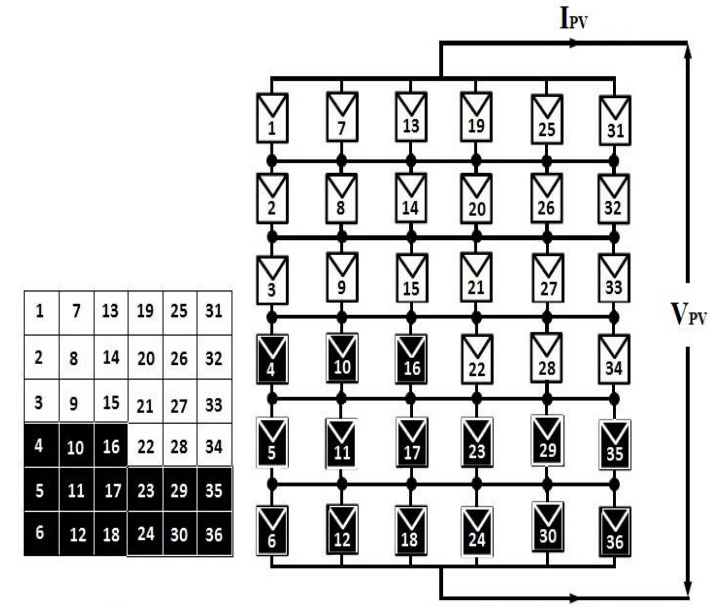

(b) Short Wide Shading (SWS) on Modules of 6x6 Solar PV Array in TCT Configuration

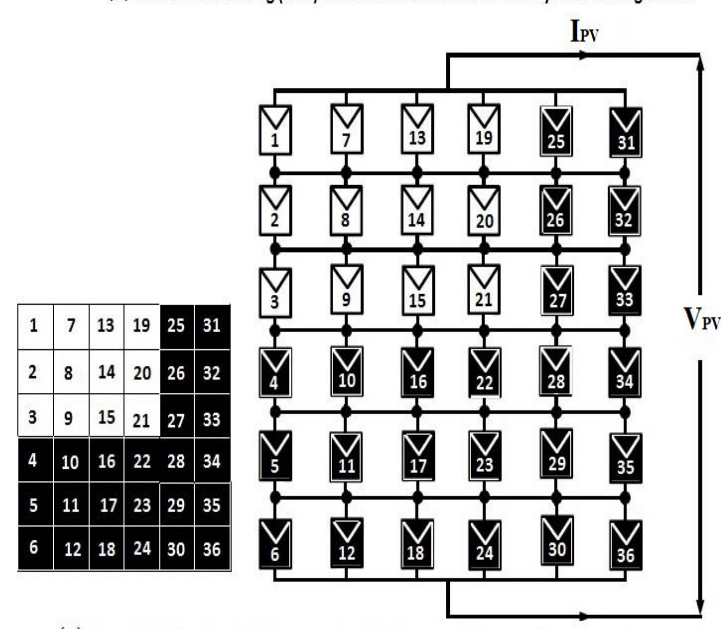

(d) Long Wide Shading (LWS) on modules of $6 \times 6$ Solar PV Array in TCT Configuration

Figure 12. $6 \times 6$ Solar array with TCT configuration under various shading conditions

The maximum generated power of SPV array configuration under uniform irradiance of $1000 \mathrm{~W} / \mathrm{m}^{2}$ is given as

$\boldsymbol{P}_{\boldsymbol{P V}}=V_{P V} \cdot I_{P V}=6 V_{m} \cdot 6 I_{m}=36 V_{m} I_{m}$

where $V_{m}$ is the maximum voltage. In the TCT topology, there are six series-connected modules, the voltage across the PV Array is $6 V_{m}$ and the array current is $4.5 I_{m}$, due to the limitation of the array current in series-connected modules in the array topology. There is no module bypassed through the bypass diode, so the array voltage is $6 V_{m}$.

In the TCT topology under short narrow shading case without bypassing the solar modules, the total array output power is given as

$\boldsymbol{P}_{\boldsymbol{P V}, \boldsymbol{T C T}}=\left(6 V_{m}\right) *\left(4.5 I_{m}\right)=27 V_{m} I_{m}$

(b) Short Wide Shading (SWS) 
The short wide shading pattern can be observed in Figure 12(b). In this shading case, PV modules in $1^{\text {st }}, 2^{\text {nd }}, 3^{\text {rd }}$ rows receive an irradiance of $1000 \mathrm{~W} / \mathrm{m}^{2}$, while the remaining modules in rows are under shaded with solar irradiance of $500 \mathrm{~W} / \mathrm{m}^{2}$. The current generated by the $1^{\text {st }}, 2^{\text {nd }}$, and $3^{\text {rd }}$ rows are calculated as follows:

$$
\boldsymbol{I}_{\boldsymbol{R} \mathbf{1}}=\boldsymbol{I}_{\boldsymbol{R} \mathbf{2}}=\boldsymbol{I}_{\boldsymbol{R} \mathbf{3}}=\left(\frac{1000}{1000}\right) I_{m}+\left(\frac{1000}{1000}\right) I_{m}+\left(\frac{1000}{1000}\right) I_{m}+\left(\frac{1000}{1000}\right) I_{m}+\left(\frac{1000}{1000}\right) I_{m}+\left(\frac{1000}{1000}\right) I_{m}=6 I_{m}
$$

Modules in row $4^{\text {th }}, 5^{\text {th }}$ and $6^{\text {th }}$ are shaded. Corresponding row currents are given by,

$$
\begin{aligned}
& \boldsymbol{I}_{\boldsymbol{R} 4}=\left(\frac{500}{1000}\right) I_{m}+\left(\frac{500}{1000}\right) I_{m}+\left(\frac{500}{1000}\right) I_{m}+\left(\frac{1000}{1000}\right) I_{m}+\left(\frac{1000}{1000}\right) I_{m}+\left(\frac{1000}{1000}\right) I_{m}=4.5 I_{m} \\
& \boldsymbol{I}_{\boldsymbol{R} 5}=\boldsymbol{I}_{\boldsymbol{R} \mathbf{6}}=\left(\frac{500}{1000}\right) I_{m}+\left(\frac{500}{1000}\right) I_{m}+\left(\frac{500}{1000}\right) I_{m}+\left(\frac{500}{1000}\right) I_{m}+\left(\frac{500}{1000}\right) I_{m}+\left(\frac{500}{1000}\right) I_{m}=3 I_{m}
\end{aligned}
$$

\section{(c) Long Narrow Shading (LNS)}

The long narrow shading pattern can be observed in Figure 12(c). In this shading case, PV modules in $1^{\text {st }}$ row receive irradiance of $1000 \mathrm{~W} / \mathrm{m}^{2}$, while the remaining modules in rows are shaded with an irradiance of $500 \mathrm{~W} / \mathrm{m}^{2}$. Then the current in $1^{\text {st }}$ row is calculated as follows:

$$
\boldsymbol{I}_{\boldsymbol{R} 1}=\left(\frac{1000}{1000}\right) I_{m}+\left(\frac{1000}{1000}\right) I_{m}+\left(\frac{1000}{1000}\right) I_{m}+\left(\frac{1000}{1000}\right) I_{m}+\left(\frac{1000}{1000}\right) I_{m}+\left(\frac{1000}{1000}\right) I_{m}=6 I_{m}
$$

PV Modules in $2^{\text {nd }}, 3^{\text {rd }}, 4^{\text {th }}, 5^{\text {th }}$ and $6^{\text {th }}$ rows are under shading, and corresponding row currents are given by,

$$
\begin{gathered}
\boldsymbol{I}_{\boldsymbol{R} \mathbf{2}}=\boldsymbol{I}_{\boldsymbol{R} \mathbf{3}}=\left(\frac{1000}{1000}\right) I_{m}+\left(\frac{1000}{1000}\right) I_{m}+\left(\frac{1000}{1000}\right) I_{m}+\left(\frac{1000}{1000}\right) I_{m}+\left(\frac{500}{1000}\right) I_{m}+\left(\frac{500}{1000}\right) I_{m}=5 I_{m} \\
\boldsymbol{I}_{\boldsymbol{R} 4}=\boldsymbol{I}_{\boldsymbol{R} \mathbf{5}}=\boldsymbol{I}_{\boldsymbol{R} \mathbf{6}}=\left(\frac{1000}{1000}\right) I_{m}+\left(\frac{1000}{1000}\right) I_{m}+\left(\frac{500}{1000}\right) I_{m}+\left(\frac{500}{1000}\right) I_{m}+\left(\frac{500}{1000}\right) I_{m}+\left(\frac{500}{1000}\right) I_{m}=4 I_{m}
\end{gathered}
$$

\section{(d) Long Wide Shading (LWS)}

The LWS shading case is observed in Figure 12(d). Assume shading modules have irradiance of $500 \mathrm{~W} / \mathrm{m}^{2}$. In this type of shading case, all rows are shaded. From Figure 9(d): In long wide shading, PV modules in all rows are under shaded with solar irradiance of $500 \mathrm{~W} / \mathrm{m}^{2}$. The current generated by the $1^{\text {st }}, 2^{\text {nd }}, 3^{\text {rd }}, 4^{\text {th }}, 5^{\text {th }}$, and $6^{\text {th }}$ rows are calculated as follows: Row current is calculated from Equation 31.

$$
\boldsymbol{I}_{\boldsymbol{R} \mathbf{1}}=\boldsymbol{I}_{\boldsymbol{R} \mathbf{2}}=\boldsymbol{I}_{\boldsymbol{R} \mathbf{3}}=\left(\frac{\mathbf{1 0 0 0}}{\mathbf{1 0 0 0}}\right) I_{m}+\left(\frac{1000}{1000}\right) I_{m}+\left(\frac{1000}{1000}\right) I_{m}+\left(\frac{1000}{1000}\right) I_{m}+\left(\frac{500}{1000}\right) I_{m}+\left(\frac{500}{1000}\right) I_{m}=5 I_{m}
$$

The PV modules in $4,5,6^{\text {th }}$ rows are shaded, and corresponding row currents are given by,

$$
\boldsymbol{I}_{\boldsymbol{R} \mathbf{4}}=\boldsymbol{I}_{\boldsymbol{R} \mathbf{5}}=\boldsymbol{I}_{\boldsymbol{R} \mathbf{6}}=\left(\frac{500}{1000}\right) I_{m}+\left(\frac{500}{1000}\right) I_{m}+\left(\frac{500}{1000}\right) I_{m}+\left(\frac{500}{1000}\right) I_{m}+\left(\frac{500}{1000}\right) I_{m}+\left(\frac{500}{1000}\right) I_{m}=3 I_{m}
$$

The currents generated in six rows in an array configuration are different due to non-uniform irradiance falling on the modules in an array configuration, which results in 
the multiple peaks occur on the output $\mathrm{P}-\mathrm{V}$ characteristics. The location of global MPP in output PV characteristics of conventional array topologies under different shading cases are tabulated in Tables 2 and 3, and the module currents in each row are based on the order in which modules were bypassed. By neglecting the voltage drops across the diodes and voltage variations across individual rows, then

The voltage of PV array is given as, $V_{P V}=6 V_{m}$.

Total Array power is given as, $\boldsymbol{P}_{\boldsymbol{P V}}=V_{P V} \cdot I_{P V}$.

In Table 2, the array current $I_{P V}{ }^{*}$ denotes the minimum of six-row currents due to series connection of six modules, and the current is limited to minimum row current. Only the minimum current will flow through the array configurations[16-17].

\section{(e) Un-Shaded Case-U:}

In the un-shade case, $36 \mathrm{PV}$ modules in a $6 \times 6$ array TCT configuration receive uniform irradiance of $1000 \mathrm{~W} / \mathrm{m}^{2}$. The parameters are calculated under uniform irradiance case by equation 24 to 28 ,

The array current $\mathbf{V P V}=6 I_{m}$

array voltage $\quad \mathbf{I P V}=6 V_{m}$ and

array power $\quad \mathbf{P} \mathbf{P V}=36 V_{m} I_{m}$.

\subsection{Theoretical Calculations and Discussions}

In this paper, mathematical analysis of a $6 \times 6$ size, solar based PV array configurations is performed under four shading cases including short narrow, short wide, long narrow, and long wide types of partial shadings, as appeared in Figures 12(a) to 12(d). Table 3 demonstrates the hypothetical figuring to determine the maximum global power for the Total-Cross-Tied PV array design. Under uniform irradiance implies the non-shading case, the TCT configuration has an extreme maximum array power of 36 $V_{m} I_{m}$; while in shading cases, the currents in each row are different because of progress in irradiance on the PV modules in an array and corresponding power also changed. In the case of short narrow shading (SNS), the minimum current is $4.5 I_{m}$ from the rows $4^{\text {th }}, 5^{\text {th }}$, $6^{\text {th }}$, and remaining row currents are equal to $6 I_{m}$. Modules are connected in series due to this; the current is limited to the minimum current of rows[16-17], so the array current is $4.5 I_{m}$, and array voltage is $6 V_{m}$. The resultant array power is $27 V_{m} I_{m}$. In the remaining three shading cases, the energy yield of the PV array TCT configuration is less than the SNS case. The theoretical results are tabulated in Table 3 for the TCT $6 \times 6$ PV array configuration. In series connections, high voltages are generated by PV modules and high currents are produced in parallel connections. In S-P and TCT connections, the output power of the array is more under short narrow case as compared to other shading cases.

From the mathematical analysis of a $6 \times 6$ size solar PV array configurations, it can be concluded that: 
* In the simple series connection type of configuration, under uniform irradiance case, the maximum current $\left(I_{m}\right)$ is produced by the SPV modules of an array. Under shading cases, limitation due to the minimum current of $0.5 I_{m}$ (is determined from Equation 31) with an irradiance of $500 \mathrm{~W} / \mathrm{m}^{2}$, the voltage is $V_{m}$ and neglect voltage drops across diodes. The resultant array power is only $18 V_{m} I_{m}$, while in uniform case it is $36 V_{m} I_{m}$. * In the simple parallel connection type of configurations, under uniform irradiance case the maximum current $\left(I_{m}\right)$ is produced in each parallel connected modules in the PV array. Under shading cases, different currents are created and determined from Equation 31. In the short narrow case, the array current and voltage is $31.5 I_{m}$ and $V_{m}$, and neglect voltage drops across diodes. The resultant array power is only $31.5 V_{m} I_{m}$, though in uniform case it is $36 V_{m} I_{m}$.

* In the Series-Parallel connection type of configurations, under uniform irradiance case the array current is the aggregate of six-string currents (series connection of modules), i.e., $6 I_{m}$, array voltage is $6 V_{m}$, and the resultant array power is $36 V_{m} I_{m}$. Under the short narrow case, because of shading with irradiance of $500 \mathrm{~W} / \mathrm{m}^{2}$, the array current is $4.5 I_{m}$, the array voltage across $6 \mathrm{PV}$ modules is $6 V_{m}$, and the resulting array power is $27 V_{m} I_{m}$.

* In the TCT connection type of configurations, under uniform irradiance case, the array current, the voltage, and the power are $6 I_{m}, 6 V_{m}$, and $36 V_{m} I_{m}$, respectively. In short narrow shading case, row 4, 5, 6 has a minimum current of $4.5 I_{m}$, and the voltage is $6 V_{m}$ (neglecting voltage drops across the diodes). When the rows in the configuration are connected in series, because of limitation in series current, the array current is limited to $4.5 \mathrm{I}_{\mathrm{m}}$ and the resultant power is $27 V_{m} I_{m}$.

* In the B-L connection type of configurations, under uniform irradiance case, the maximum array current in parallel strings is $6 I_{m}$, the voltage is $6 V_{m}$ and the array power is $36 V_{m} I_{m}$. Under different shading cases, the output power of the array is changed.

* In the H-C connection type of configurations, under uniform irradiance case, the array current is $6 I_{m}$, the voltage is $6 V_{m}$ and the power is $36 V_{m} I_{m}$. The output power of an array configuration is changed, and it depends upon the shading pattern.

Theoretical calculations of different solar PV array configurations are presented in Table 2 and 3.

Table 2. Theoretical calculations of the location of GMPP in PV array with $S, P$ and S-P configurations under irradiance of $500 \mathrm{~W} / \mathrm{m}^{2}$

\begin{tabular}{|l|c|c|c|c|c|c|c|c|c|}
\hline Configuration & \multicolumn{3}{|c|}{ Simple Series } & \multicolumn{3}{c|}{ Simple Parallel } & \multicolumn{3}{c|}{ Series-Parallel } \\
\hline Shadow Cases & $\begin{array}{c}\text { Array } \\
\text { Current } \\
\left(\mathrm{I}_{\mathrm{PV}}\right)\end{array}$ & $\begin{array}{c}\text { Array } \\
\text { Voltage } \\
\left(\mathrm{V}_{\mathrm{PV}}\right)\end{array}$ & $\begin{array}{c}\text { Array } \\
\text { Power } \\
\left(\mathrm{P}_{\mathrm{PV}}\right)\end{array}$ & $\begin{array}{c}\text { Array } \\
\text { Current } \\
\left(\mathrm{I}_{\mathrm{PV}}\right)\end{array}$ & $\begin{array}{c}\text { Array } \\
\text { Voltage } \\
\left(\mathrm{V}_{\mathrm{PV}}\right)\end{array}$ & $\begin{array}{c}\text { Array } \\
\text { Power } \\
\left(\mathrm{P}_{\mathrm{PV}}\right)\end{array}$ & $\begin{array}{c}\text { Array } \\
\text { Current } \\
\left(\mathrm{I}_{\mathrm{PV}}\right)\end{array}$ & $\begin{array}{c}\text { Array } \\
\text { Voltage } \\
\left(\mathrm{V}_{\mathrm{PV}}\right)\end{array}$ & $\begin{array}{c}\text { Array } \\
\text { Power } \\
\left(\mathbf{P}_{\mathrm{PV}}\right)\end{array}$ \\
\hline Uniform case & $\mathrm{I}_{\mathrm{PV}}=\mathrm{I}_{\mathrm{m}}$ & $36 \mathrm{~V}_{\mathrm{m}}$ & $36 \mathrm{~V}_{\mathrm{m}} \cdot \mathrm{I}_{\mathrm{m}}$ & $\mathrm{I}_{\mathrm{PV}}=36 \mathrm{I}_{\mathrm{m}}$ & $\mathrm{V}_{\mathrm{m}}$ & $36 \mathrm{~V}_{\mathrm{m}} \cdot \mathrm{I}_{\mathrm{m}}$ & $\mathrm{I}_{\mathrm{PV}}=6 \mathrm{I}_{\mathrm{m}}$ & $6 \mathrm{~V}_{\mathrm{m}}$ & $36 \mathrm{~V}_{\mathrm{m}} \cdot \mathrm{I}_{\mathrm{m}}$ \\
\hline Short Narrow & $\mathrm{I}_{\mathrm{PV}}=0.5 \mathrm{I}_{\mathrm{m}}$ & $36 \mathrm{~V}_{\mathrm{m}}$ & $18 \mathrm{~V}_{\mathrm{m}} \cdot \mathrm{I}_{\mathrm{m}}$ & $\mathrm{I}_{\mathrm{PV}}=31.5 \mathrm{I}_{\mathrm{m}}$ & $\mathrm{V}_{\mathrm{m}}$ & $31.5 \mathrm{~V}_{\mathrm{m}} \cdot \mathrm{I}_{\mathrm{m}}$ & $\mathrm{I}_{\mathrm{PV}}=4.5 \mathrm{I}_{\mathrm{m}}$ & $6 \mathrm{~V}_{\mathrm{m}}$ & $27 \mathrm{~V}_{\mathrm{m}} \cdot \mathrm{I}_{\mathrm{m}}$ \\
\hline Short Wide & $\mathrm{I}_{\mathrm{PV}}=0.5 \mathrm{I}_{\mathrm{m}}$ & $36 \mathrm{~V}_{\mathrm{m}}$ & $18 \mathrm{~V}_{\mathrm{m}} \cdot \mathrm{I}_{\mathrm{m}}$ & $\mathrm{I}_{\mathrm{PV}}=28.5 \mathrm{I}_{\mathrm{m}}$ & $\mathrm{V}_{\mathrm{m}}$ & $28.5 \mathrm{~V}_{\mathrm{m}} \cdot \mathrm{I}_{\mathrm{m}}$ & $\mathrm{I}_{\mathrm{PV}}=3 \mathrm{I}_{\mathrm{m}}$ & $6 \mathrm{~V}_{\mathrm{m}}$ & $18 \mathrm{~V}_{\mathrm{m}} \cdot \mathrm{I}_{\mathrm{m}}$ \\
\hline Long Narrow & $\mathrm{I}_{\mathrm{PV}}=0.5 \mathrm{I}_{\mathrm{m}}$ & $36 \mathrm{~V}_{\mathrm{m}}$ & $18 \mathrm{~V}_{\mathrm{m}} \cdot \mathrm{I}_{\mathrm{m}}$ & $\mathrm{I}_{\mathrm{PV}}=28 \mathrm{I}_{\mathrm{m}}$ & $\mathrm{V}_{\mathrm{m}}$ & $28 \mathrm{~V}_{\mathrm{m}} \cdot \mathrm{I}_{\mathrm{m}}$ & $\mathrm{I}_{\mathrm{PV}}=4 \mathrm{I}_{\mathrm{m}}$ & $6 \mathrm{~V}_{\mathrm{m}}$ & $24 \mathrm{~V}_{\mathrm{m}} \cdot \mathrm{I}_{\mathrm{m}}$ \\
\hline Long Wide & $\mathrm{I}_{\mathrm{PV}}=0.5 \mathrm{I}_{\mathrm{m}}$ & $36 \mathrm{~V}_{\mathrm{m}}$ & $18 \mathrm{~V}_{\mathrm{m}} \cdot \mathrm{I}_{\mathrm{m}}$ & $\mathrm{I}_{\mathrm{PV}}=24 \mathrm{I}_{\mathrm{m}}$ & $\mathrm{V}_{\mathrm{m}}$ & $24 \mathrm{~V}_{\mathrm{m}} \cdot \mathrm{I}_{\mathrm{m}}$ & $\mathrm{I}_{\mathrm{PV}}=3 \mathrm{I}_{\mathrm{m}}$ & $6 \mathrm{~V}_{\mathrm{m}}$ & $18 \mathrm{~V}_{\mathrm{m}} \cdot \mathrm{I}_{\mathrm{m}}$ \\
\hline
\end{tabular}


Table 3. Theoretical calculations of the location of GMPP in SPV Array with TCT configuration under irradiance of $500 \mathrm{~W} / \mathrm{m}^{2}$

\begin{tabular}{|c|c|c|c|c|}
\hline $\begin{array}{c}\text { Shading } \\
\text { Cases }\end{array}$ & $\begin{array}{c}\text { Order of row currents } \\
\text { in which the modules } \\
\text { are bypassed }\left(I_{R}\right) \\
\end{array}$ & $\begin{array}{c}\text { Array } \\
\text { Voltage } \\
\left(V_{R}\right) \\
\end{array}$ & $\begin{array}{l}\text { Array Power } \\
\left(P_{P V}=V_{R} . I_{R}\right)\end{array}$ & $\begin{array}{c}\text { Location of } \\
\text { GMPP } \\
\left(P_{P V}\right) \\
\end{array}$ \\
\hline $\begin{array}{l}\text { Un-Shaded } \\
\text { Case }(\mathbf{U})\end{array}$ & $\begin{array}{l}\mathrm{I}_{\mathrm{R} 6}=6 \mathrm{I}_{\mathrm{m}} \\
\mathrm{I}_{\mathrm{R} 5}=6 \mathrm{I}_{\mathrm{m}} \\
\mathrm{I}_{\mathrm{R} 4}=6 \mathrm{I}_{\mathrm{m}} \\
\mathrm{I}_{\mathrm{R} 3}=6 \mathrm{I}_{\mathrm{m}} \\
\mathrm{I}_{\mathrm{R} 2}=6 \mathrm{I}_{\mathrm{m}} \\
\mathrm{I}_{\mathrm{R} 1}=6 \mathrm{I}_{\mathrm{m}}\end{array}$ & $\begin{array}{l}6 \mathrm{~V}_{\mathrm{m}} \\
6 \mathrm{~V}_{\mathrm{m}} \\
6 \mathrm{~V}_{\mathrm{m}} \\
6 \mathrm{~V}_{\mathrm{m}} \\
6 \mathrm{~V}_{\mathrm{m}} \\
6 \mathrm{~V}_{\mathrm{m}}\end{array}$ & $\begin{array}{l}36 \mathrm{~V}_{\mathrm{m}} \cdot \mathrm{I}_{\mathrm{m}} \\
36 \mathrm{~V}_{\mathrm{m}} \cdot \mathrm{I}_{\mathrm{m}} \\
36 \mathrm{~V}_{\mathrm{m}} \cdot \mathrm{I}_{\mathrm{m}} \\
36 \mathrm{~V}_{\mathrm{m}} \cdot \mathrm{I}_{\mathrm{m}} \\
36 \mathrm{~V}_{\mathrm{m}} \cdot \mathrm{I}_{\mathrm{m}} \\
36 \mathrm{~V}_{\mathrm{m}} \cdot \mathrm{I}_{\mathrm{m}}\end{array}$ & $36 V_{m} \cdot I_{m}$ \\
\hline $\begin{array}{c}\text { Short } \\
\text { Narrow } \\
\text { Shading } \\
\text { (SNS) }\end{array}$ & $\begin{aligned} \boldsymbol{I}_{\boldsymbol{R} 6} & =4.5 \mathrm{I}_{\boldsymbol{m}} \\
\mathrm{I}_{\mathrm{R} 5} & =4.5 \mathrm{I}_{\mathrm{m}} \\
\mathrm{I}_{\mathrm{R} 4} & =4.5 \mathrm{I}_{\mathrm{m}} \\
\mathrm{I}_{\mathrm{R} 3} & =6 \mathrm{I}_{\mathrm{m}} \\
\mathrm{I}_{\mathrm{R} 2} & =6 \mathrm{I}_{\mathrm{m}} \\
\mathrm{I}_{\mathrm{R} 1} & =6 \mathrm{I}_{\mathrm{m}}\end{aligned}$ & $\begin{array}{l}6 V_{m} \\
5 V_{m} \\
4 V_{m} \\
3 V_{m} \\
2 V_{m} \\
V_{m}\end{array}$ & $\begin{array}{c}27 V_{m} \cdot I_{m} \\
22.5 \mathrm{~V}_{\mathrm{m}} \cdot \mathrm{I}_{\mathrm{m}} \\
18 \mathrm{~V}_{\mathrm{m}} \cdot \mathrm{I}_{\mathrm{m}} \\
18 \mathrm{~V}_{\mathrm{m}} \cdot \mathrm{I}_{\mathrm{m}} \\
12 \mathrm{~V}_{\mathrm{m}} \cdot \mathrm{I}_{\mathrm{m}} \\
6 \mathrm{~V}_{\mathrm{m}} \cdot \mathrm{I}_{\mathrm{m}}\end{array}$ & $27 V_{m .} I_{m}$ \\
\hline $\begin{array}{l}\text { Short Wide } \\
\text { Shading } \\
\text { (SWS) }\end{array}$ & $\begin{aligned} \boldsymbol{I}_{\boldsymbol{R} \boldsymbol{6}} & =\mathbf{3} \mathrm{I}_{\boldsymbol{m}} \\
\mathrm{I}_{\mathrm{R} 5} & =3 \mathrm{I}_{\mathrm{m}} \\
\mathrm{I}_{\mathrm{R} 4} & =4.5 \mathrm{I}_{\mathrm{m}} \\
\mathrm{I}_{\mathrm{R} 3} & =6 \mathrm{I}_{\mathrm{m}} \\
\mathrm{I}_{\mathrm{R} 2} & =6 \mathrm{I}_{\mathrm{m}} \\
\mathrm{I}_{\mathrm{R} 1} & =6 \mathrm{I}_{\mathrm{m}}\end{aligned}$ & $\begin{array}{l}6 V_{m} \\
5 V_{m} \\
4 V_{m} \\
3 V_{m} \\
2 V_{m} \\
V_{m} \\
\end{array}$ & $\begin{array}{l}18 V_{m} \cdot I_{m} \\
15 \mathrm{~V}_{\mathrm{m}} \cdot \mathrm{I}_{\mathrm{m}} \\
18 \mathrm{~V}_{\mathrm{m}} \cdot \mathrm{I}_{\mathrm{m}} \\
18 \mathrm{~V}_{\mathrm{m}} \cdot \mathrm{I}_{\mathrm{m}} \\
12 \mathrm{~V}_{\mathrm{m}} \cdot \mathrm{I}_{\mathrm{m}} \\
6 \mathrm{~V}_{\mathrm{m}} \cdot \mathrm{I}_{\mathrm{m}}\end{array}$ & $18 V_{m .} I_{m}$ \\
\hline $\begin{array}{c}\text { Long } \\
\text { Narrow } \\
\text { Shading } \\
\text { (LNS) }\end{array}$ & $\begin{array}{l}\boldsymbol{I}_{\boldsymbol{R} \boldsymbol{6}}=4 \mathrm{I}_{\boldsymbol{m}} \\
\mathrm{I}_{\mathrm{R} 5}=4 \mathrm{I}_{\mathrm{m}} \\
\mathrm{I}_{\mathrm{R} 4}=4 \mathrm{I}_{\mathrm{m}} \\
\mathrm{I}_{\mathrm{R} 3}=5 \mathrm{I}_{\mathrm{m}} \\
\mathrm{I}_{\mathrm{R} 2}=5 \mathrm{I}_{\mathrm{m}} \\
\mathrm{I}_{\mathrm{R} 1}=6 \mathrm{I}_{\mathrm{m}}\end{array}$ & $\begin{array}{l}6 V_{m} \\
5 V_{m} \\
4 V_{m} \\
3 V_{m} \\
2 V_{m} \\
V_{m}\end{array}$ & $\begin{array}{l}\mathbf{2 4} \boldsymbol{V}_{\boldsymbol{m} \cdot I_{\boldsymbol{m}}} \\
20 \mathrm{~V}_{\mathrm{m}} \cdot \mathrm{I}_{\mathrm{m}} \\
16 \mathrm{~V}_{\mathrm{m}} \cdot \mathrm{I}_{\mathrm{m}} \\
15 \mathrm{~V}_{\mathrm{m}} \cdot \mathrm{I}_{\mathrm{m}} \\
10 \mathrm{~V}_{\mathrm{m}} \cdot \mathrm{I}_{\mathrm{m}} \\
6 \mathrm{~V}_{\mathrm{m}} \cdot \mathrm{I}_{\mathrm{m}}\end{array}$ & $24 V_{m .} I_{m}$ \\
\hline $\begin{array}{l}\text { Long Wide } \\
\text { Shading } \\
\text { (LWS) }\end{array}$ & $\begin{aligned} \boldsymbol{I}_{\boldsymbol{R} 6} & =3 \mathrm{I}_{m} \\
\mathrm{I}_{\mathrm{R} 5} & =3 \mathrm{I}_{\mathrm{m}} \\
\mathrm{I}_{\mathrm{R} 4} & =3 \mathrm{I}_{\mathrm{m}} \\
\mathrm{I}_{\mathrm{R} 3} & =5 \mathrm{I}_{\mathrm{m}} \\
\mathrm{I}_{\mathrm{R} 2} & =5 \mathrm{I}_{\mathrm{m}} \\
\mathrm{I}_{\mathrm{R} 1} & =5 \mathrm{I}_{\mathrm{m}}\end{aligned}$ & $\begin{array}{l}6 V_{m} \\
5 V_{m} \\
4 V_{m} \\
3 V_{m} \\
2 V_{m} \\
V_{m}\end{array}$ & $\begin{array}{l}18 \boldsymbol{V}_{\boldsymbol{m}} \cdot \mathbf{I}_{\boldsymbol{m}} \\
15 \mathrm{~V}_{\mathrm{m}} \cdot \mathrm{I}_{\mathrm{m}} \\
12 \mathrm{~V}_{\mathrm{m}} \cdot \mathrm{I}_{\mathrm{m}} \\
15 \mathrm{~V}_{\mathrm{m}} \cdot \mathrm{I}_{\mathrm{m}} \\
10 \mathrm{~V}_{\mathrm{m}} \cdot \mathrm{I}_{\mathrm{m}} \\
6 \mathrm{~V}_{\mathrm{m}} \cdot \mathrm{I}_{\mathrm{m}}\end{array}$ & $18 V_{m} I_{m}$ \\
\hline
\end{tabular}

\subsection{Simulation Results}

The $6 \times 6$ solar PV array conventional topologies, mainly S-P, TCT, BL, HC types of models, are developed and simulated in Matlab/Simulink software. The Vikram solar ELDORA 270W [ $\mathrm{P}_{\max }$ is $270 \mathrm{~W}$ ] panel specifications are used in simulation of a $6 \times 6$ size SPV array with S-P, TCT, BL and HC configurations under SNS,SWS,LNS,LWS shading cases. The simulation results are tabulated in Table 4, and the maximum PV array powers observed in the TCT topology are $7714 \mathrm{~W}, 5478 \mathrm{~W}, 6865 \mathrm{~W}$, and $5284 \mathrm{~W}$ 
under proposed four shading cases, respectively. The output characteristics (V-P) of different array configurations are appeared in Figures 13 to 16.

Table 4. Simulation results of a $6 \times 6$ solar PV array configurations under different shading cases

\begin{tabular}{|l|c|c|c|c|}
\hline \multirow{2}{*}{\begin{tabular}{c} 
Configuration $\begin{array}{c}\text { Vs } \\
\text { Shading Cases }\end{array}$ \\
\cline { 2 - 5 }
\end{tabular}} & $\begin{array}{c}\text { Series-Parallel } \\
\text { (S-P) }\end{array}$ & $\begin{array}{c}\text { Total-Cross-Tied } \\
\text { (TCT) }\end{array}$ & $\begin{array}{c}\text { Bridge-Linked } \\
\text { (BL) }\end{array}$ & $\begin{array}{c}\text { Honey-Comb } \\
\text { (HC) }\end{array}$ \\
\hline Uniform case & \multicolumn{4}{|c|}{ Array Power-P } \\
Short Narrow & 9620 & 9620 & 9620 & 9620 \\
\hline Short Wide & 7384 & 7714 & 7565 & 7414 \\
\hline Long Narrow & 5412 & 5478 & 5407 & 5434 \\
\hline Long Wide & 5604 & 6865 & 6765 & 5732 \\
\hline
\end{tabular}

i. S-P Configuration P-V Characteristics

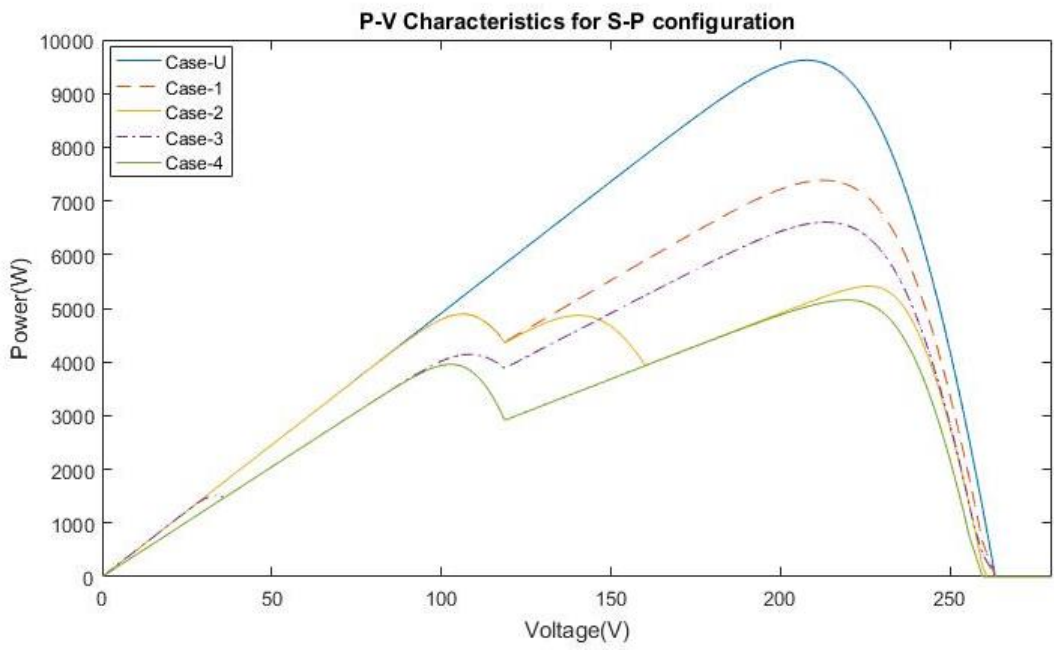

Figure 13. PV Curves for S-P type connection

\section{ii. TCT Configuration P-V Characteristics}

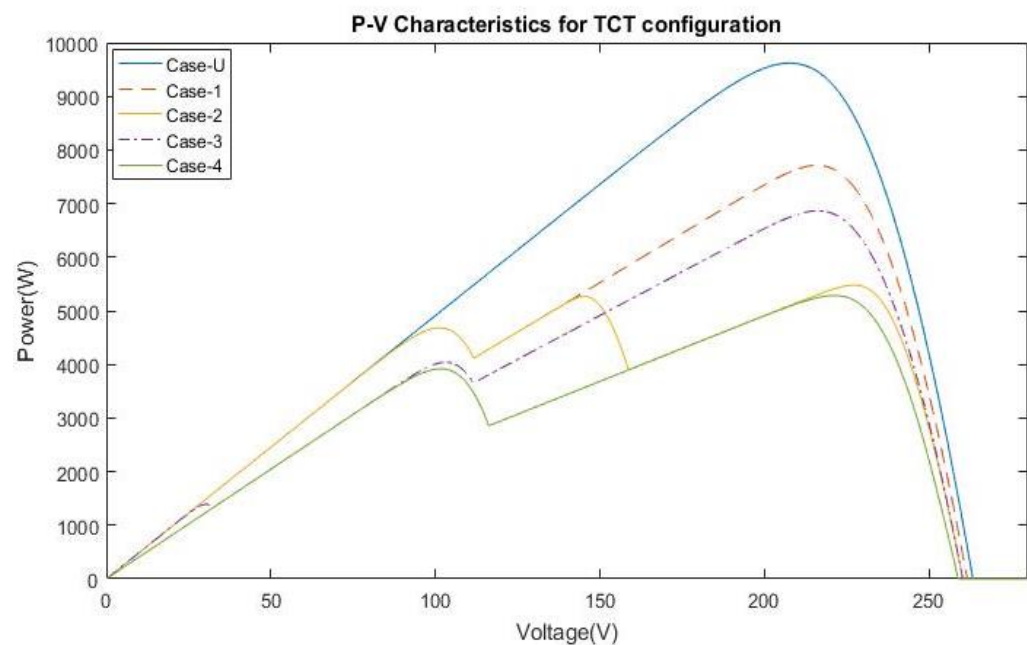

Figure 14. PV Curves for TCT type connection 
iii. B-L Configuration P-V Characteristics

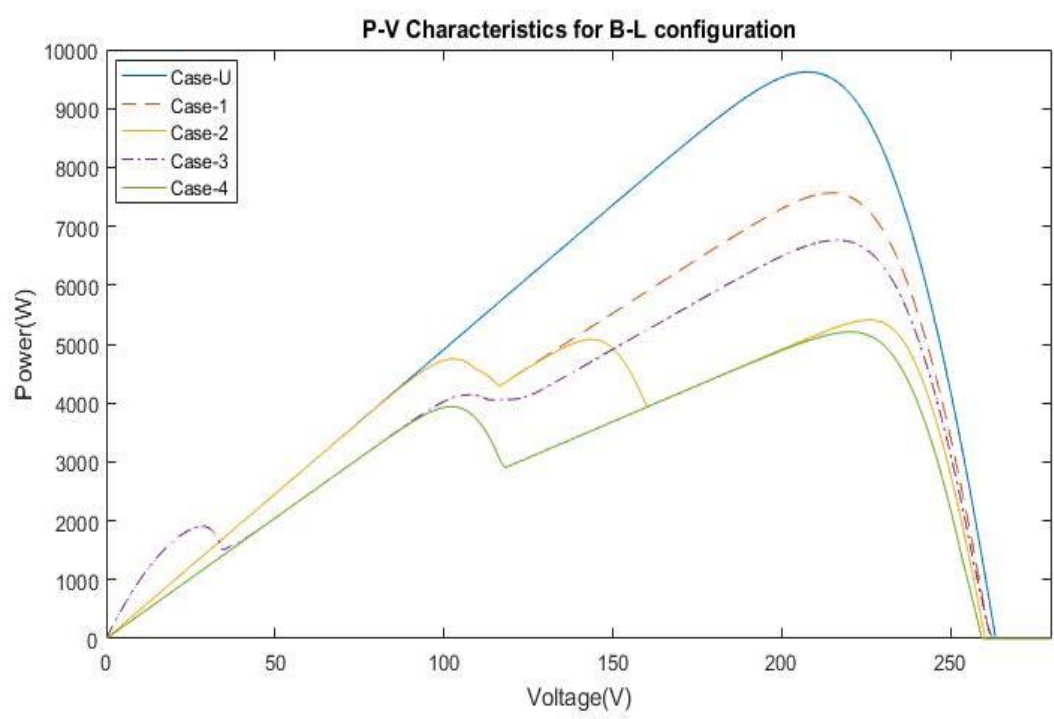

Figure 15. PV Curves for B-L type connection

iv. H-C Configuration P-V Characteristics

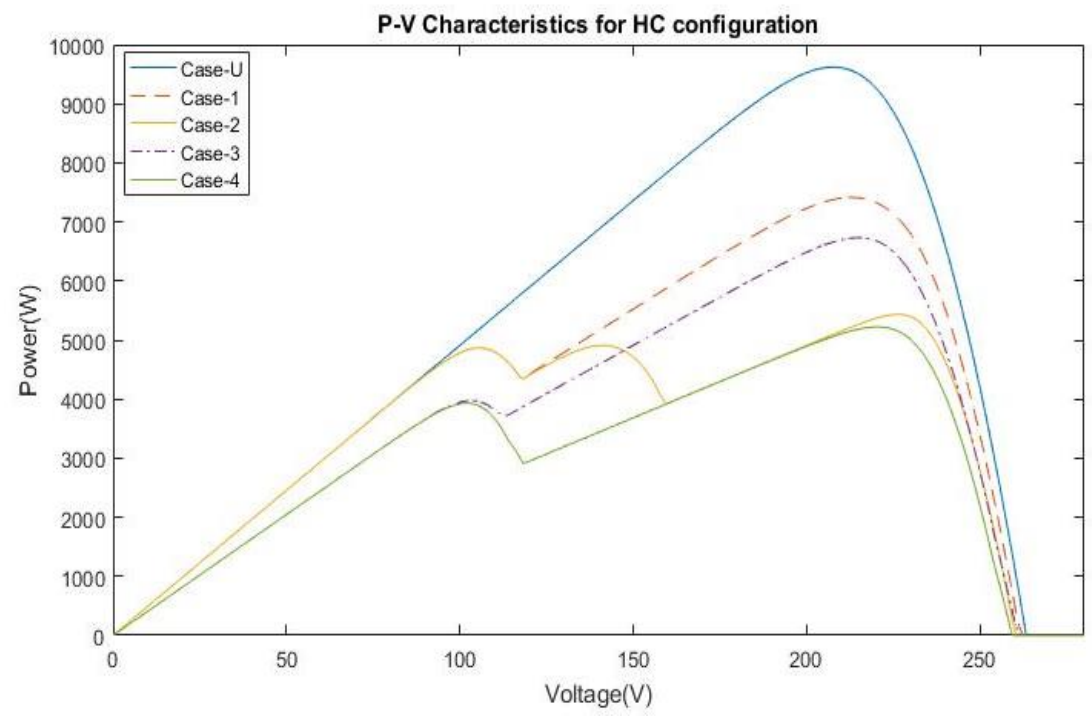

Figure 16. PV Curves for HC type connection

\section{CONCLUSIONS}

In this paper, mathematical investigation of conventional solar PV array configurations in particularly SS, P, SP, TCT, BL and HC types under uniform irradiance case, i.e., non-shading case and proposed partial shading cases including short narrow, short wide, long narrow and long wide shading cases are presented. The $6 \times 6$ size solar PV array configurations are considered for examining under non-shading and partial 
shading cases. Under various shading cases, each row current is determined based on the order of row currents, in which the modules are bypassed for the identification of a global peak power position in the output characteristics of different PV array configurations. This mathematical analysis is based on the KVL and KCL equations of a different module connections in a PV array. From the theoretical calculations and simulation analysis, the array output power is greater in TCT configuration under short narrow shading conditions. It can be concluded that the energy yield of an array relies upon the shading pattern in the SPV array configurations.

\section{CONFLICTS OF INTEREST}

The authors declare that there is no conflict of interests regarding the publication of this paper.

\section{REFERENCES}

[1] Fahrenbruch, A., and Bube, R. (2012). Fundamentals of solar cells: photovoltaic solar energy conversion, Elsevier

[2] Dirk, A., Assmann, D., Laumanns, U., and Uh, D. (2006). Renewable energy: a global review of technologies, policies and markets, Routledge

[3] Kumar, A., Pachauri, R. K., and Chauhan, Y. K. Experimental analysis of SP/TCT PV array configurations under partial shading conditions. In: Proc., 2016 IEEE 1st International Conference on Power Electronics, Intelligent Control and Energy Systems (ICPEICES), pp: 1-6. DOI: 10.1109/icpeices.2016.7853403

[4] Bingöl, O., and Özkaya, B. (2018). Analysis and comparison of different PV array configurations under partial shading conditions. Solar Energy, 160, 336-343. DOI: 10.1016/j.solener.2017.12.004

[5] Pendem, S. R., and Mikkili, S. (2018). Modelling and performance assessment of PV array topologies under partial shading conditions to mitigate the mismatching power losses. Solar Energy, 160, 303-321. DOI: 10.1016/j.solener.2017.12.010

[6] Nguyen, D., and Lehman, B. A reconfigurable solar photovoltaic array under shadow conditions. In: Proc., 2008 Twenty-Third Annual IEEE Applied Power Electronics Conference and Exposition, IEEE, pp: 980-986

[7] Parlak, K. Ş. (2014). PV array reconfiguration method under partial shading conditions. International Journal of Electrical Power \& Energy Systems, 63, 713-721. DOI: 10.1016/j.ijepes.2014.06.042

[8] Rani, B. I., Ilango, G. S., and Nagamani, C. (2013). Enhanced power generation from PV array under partial shading conditions by shade dispersion using $\mathrm{Su}$ Do $\mathrm{Ku}$ configuration. IEEE Transactions on sustainable energy, 4(3), 594-601

[9] Wang, Y.-J., and Hsu, P.-C. (2011). An investigation on partial shading of PV modules with different connection configurations of PV cells. Energy, 36(5), 30693078. DOI: 10.1016/j.energy.2011.02.052 
[10] Tatabhatla, V. M. R., Agarwal, A., and Kanumuri, T. (2019). Improved power generation by dispersing the uniform and non-uniform partial shades in solar photovoltaic array. Energy Conversion and Management, 197, 111825. DOI: 10.1016/j.enconman.2019.111825

[11] Krishna, G. S., and Moger, T. (2019). Enhancement of maximum power output through reconfiguration techniques under non-uniform irradiance conditions. Energy, 187, 115917. DOI: 10.1016/j.energy.2019.115917

[12] Raju, V.B., and Chengaiah, Ch. (2019). Performance Analysis of Conventional, Hybrid and Optimal PV Array Configurations of Partially Shaded Modules. International Journal of Engineering and Advanced Technology, 9(1), 3061-3073. DOI: 10.35940/ijeat.A1661.109119

[13] Chao, K.-H., Lai, P.-L., and Liao, B.-J. (2015). The optimal configuration of photovoltaic module arrays based on adaptive switching controls. Energy Conversion and Management, 100, 157-167. DOI: 10.1016/j.enconman.2015.04.080

[14] Zhu, L., Li, Q., Chen, M., Cao, K., and Sun, Y. (2019). A simplified mathematical model for power output predicting of Building Integrated Photovoltaic under partial shading conditions. Energy Conversion and Management, 180, 831-843. DOI: https://doi.org/10.1016/j.enconman.2018.11.036

[15] Belhachat, F., and Larbes, C. (2015). Modeling, analysis and comparison of solar photovoltaic array configurations under partial shading conditions. Solar Energy, 120, 399-418. DOI: https://doi.org/10.1016/j.solener.2015.07.039

[16] Xiaoguang Liu and Yuefeng Wang. Reconfiguration Method to Extract more Power from Partially Shaded Photovoltaic Arrays with Series-Parallel Topology. Energies 2019, 12, 1439; DOI:10.3390/en12081439

[17] F. Spertino and J. S. Akilimali. Are Manufacturing I-V and P-V Mismatch and Reverse Currents Key Factors in Large Photovoltaic Arrays?. IEEE Transactions on Industrial Electronics, vol. 56, pp. 4520-4531, 2009. DOI: 10.1109/TIE.2009.2025712

Article copyright: (C) 2020 V. Bala Raju, Dr. Ch. Chengaiah. This is an open access article distributed under the terms of the Creative Commons Attribution 4.0 International License, which permits unrestricted use and distribution provided the original author and source are credited. 